Dariusz STOLICKI

Uniwersytet Jagielloński

dariusz.stolicki@uj.edu.pl

\title{
RAMY PRAWNE REŻIMU DETENCJI WOJSKOWEJ W PRAWIE AMERYKAŃSKIM W ŚWIETLE AKTUALNEGO ORZECZNICTWA
}

ABSTRACT Military detention framework in American law - analysis of current case law The practice of military detention of persons captured during the "global war on terror" has raised controversy both in the United States and abroad. This article, being the first in a series of articles analyzing the post-2001 case law on military detention, focuses on the basic legal framework. The principal legal basis for military detention is the 2001 Congressional Authorization of Use of Military Force against organizations responsible for 9/11 attacks. Bush and Obama Administrations' claim that the AUMF authorizes military detention has been accepted by the Supreme Court in a 2004 case Hamdi v. Rumsfeld and codified by Congress in 2011 . The article briefly considers and rejects main objections against its constitutionality. More complex are the issues raised by the application of other legal rules that potentially apply to military detention: Due Process clause of the U.S. Constitution and international law of armed conflict, but under the current D.C. Circuit case law, neither of them limits the President's detention authority. Instead, judges decide habeas corpus claims brought by the detainees on the basis of judge-made common law rules.

Słowa kluczowe: detencja wojskowa, Guantanamo, „wojna z terroryzmem”, prawo bezpieczeństwa narodowego

Keywords: military detention, Guantanamo, "war on terror", law of national security 
W odpowiedzi na ataki terrorystyczne z 11 września 2001 r. Kongres USA uchwalił rezolucję upoważniającą prezydenta do użycia siły przeciwko krajom, organizacjom i osobom, które uzna on za odpowiedzialne za wspomniane ataki ${ }^{1}$ W oparciu o tę rezolucję prezydent George W. Bush zainicjował 7 października operację antyterrorystyczną Enduring Freedom ${ }^{2}$, w której trakcie siły amerykańskie przeprowadziły interwencję zbrojną w Afganistanie i obaliły kontrolujący większą część tego kraju reżim talibów, udzielający schronienia kierownictwu Al-Kaidy, organizacji odpowiedzialnej za ataki z 11 września ${ }^{3}$. W toku tej operacji, a także innych działań antyterrorystycznych Amerykanie pojmali ok. $640^{4}$ osób uznanych za wrogich kombatantów 5 . Osoby te zostały uwięzione w bazie marynarki w zatoce Guantánamo na Kubie. USA nie przyznały im statusu jeńców wojennych ani też nie postawiły większości z nich zarzutów karnych. Nie otrzymali też oni dostępu do pomocy prawnej ${ }^{6}$.

Praktyka ta wywołała liczne kontrowersje, zarówno w Stanach Zjednoczonych, jak i poza nimi. Celem tego artykułu jest więc analiza legalności uwięzienia wymienionych osób, jak też innych pojmanych w ramach "globalnej wojny z terroryzmem" z punktu widzenia amerykańskiego prawa wewnętrznego. Artykuł przedstawia ogólne ramy prawne obecnego reżimu detencji wojskowej (military detention) ${ }^{8}$, identyfikując jego podstawę prawną i inne źródła norm wpływających na jego kształt. Stanowi on też punkt wyjścia dla będącego w przygotowaniu drugiego artykułu, przedstawiającego wypracowane przez sądy materialne normy prawa detencji wojskowej.

Problem stosowania detencji wojskowej w wojnie z terroryzmem praktycznie od samego początku budził zainteresowanie badaczy. W pierwszym okresie większość opra-

Authorization for Use of Military Force, Sept. 18, 2001, Pub. L. No. 107-40, 115 Stat. 224 (2001) (cyt. dalej: AUMF).

2 G. W. Bush, Letter to Congressional Leaders Reporting on Combat Action in Afghanistan against al Qaida Terrorists and Their Taliban Supporters, 9 X 2001, 107 $7^{\text {th }}$ Cong., $1^{\text {st }}$ Sess., 2001 Week. Comp. Pres. Doc. 1447.

3 National Commission on Terrorist Attacks Upon the United States, Final Report, Washington 2004, [online] http://www.gpo.gov/fdsys/pkg/GPO-911REPORT/pdf/GPO-911REPORT.pdf, 12 V 2013.

4 Brief for United States, Rasul v. Bush, Docket No. 03-334, 542 U.S. 466 (U.S. 2004), 3 III 2004, s. 6.

5 Zob. Notice, Detention, Treatment, and Trial of Certain Non-Citizens in the War against Terrorism, Presidential Military Order, 66 F.R. 57,833 (13 XI 2001).

6 Appendix to the Petition for Certiorari, Rasul v. Bush, Docket No. 03-343, 542 U.S. 466 (U.S. 2003), 2 IX 2003, s. 29, 77, 108.

7 Określenie „globalna wojna z terroryzmem” używane jest w tym artykule wyłącznie dla określenia konfliktu zbrojnego prowadzonego przez USA przeciw Al-Kaidzie i stowarzyszonym z nią siłom w oparciu o rezolucję z 18 IX $2001 \mathrm{r}$. Zob. J. B. Bellinger III, Legal Issues in the War on Terrorism, Address at the London School of Economics, London, 31 X 2006. Przy wszystkich niedoskonałościach tego terminu (w tej kwestii zob. J. S. Baker Jr., $A$ War, Yes; against Terror, No, „Michigan State Journal of International Law" 2011, Vol. 19, s. 119), brak alternatywnej nazwy dla konfliktu z Al-Kaidą uzasadnia dalsze jego wykorzystywanie.

8 W polskiej literaturze wciąż nie przyjęto wystarczająco precyzyjnego odpowiednika amerykańskiego określenia military detention, oznaczającego prewencyjne pozbawienie wolności członków sił nieprzyjacielskich na mocy prawa wojny, co uzasadnia przedstawienie własnej propozycji. 
cowań odwoływała się do ogólnych norm konstytucyjnych i prawa międzynarodowego. Najważniejszą próbę kompleksowej analizy ustawowej autoryzacji dla wojny z terroryzmem i interpretującego ją orzecznictwa podjęli wówczas Curtis A. Bradley i Jack L. Goldsmith' W drugim okresie, po decyzji Sądu Najwyższego w sprawie Boumediene v. Bush ${ }^{10}$, otwierającej osadzonym w Guantánamo możliwość występowania do sądów federalnych o habeas corpus ${ }^{11}$, badacze poświęcili się analizie orzeczeń sądów dystryktowych ${ }^{12}$. Jednak po 2010 r. opracowania te zaczęły tracić na aktualności, gdyż Sąd Apelacyjny dla Okręgu Dystrykt Kolumbia w wielu kwestiach zajął odmienne stanowisko. Prace analizujące jego orzecznictwo są niestety nieliczne; wymienić tu trzeba przede wszystkim artykuły Roberta M. Chesneya ${ }^{13}$ oraz Stephena I. Vladecka ${ }^{14}$ oraz raport The Emerging Law of Detention 2.0 Benjamina Wittesa, Roberta M. Chesneya i Larkin Reynolds ${ }^{15}$. Tymczasem od 2012 r., kiedy to sądy rozstrzygnęły już pierwszą grupę spraw o habeas definiujących prawo detencji wojskowej, zaś Kongres ustawowo zatwierdził najważniejsze ustalenia sądowe ${ }^{16}$, można mówić o ustabilizowaniu się stanu prawnego. Uzasadnia to potrzebę podsumowania decyzji w kwestiach już finalnie rozstrzygniętych, a także zidentyfikowania obszarów wciąż spornych.

Przedstawiony problem analizowany będzie wyłącznie z perspektywy amerykańskiego prawa wewnętrznego. Normy prawa międzynarodowego będą uwzględniane

9 C. A. Bradley, J. L. Goldsmith, Congressional Authorization and the War on Terrorism, „Harvard Law Review" 2005, Vol. 118, s. 2047.

10 Boumediene v. Bush, 553 U.S. 723 (2008).

11 Writ of habeas corpus jest nadzwyczajnym środkiem ochrony prawnej w systemach common law, służącym zaskarżeniu bezprawnego pozbawienia wolności osobistej (zwłaszcza przez podmiot działający sub colore iuris). Zob. ogólnie R. H. Fallon [i in.], Hart and Wechsler's Federal Courts and the Federal System, New York 2003, s. 1284 et seq., University Casebook Series; R. Hertz, J. S. Liebman, Federal Habeas Corpus Practice and Procedure, New Providence 2011, \$\$ 2:1 et seq.; W. Blackstone, Commentaries on the Laws of England (1765-1769), red. G. Sharswood, B. Field, t. 2, Philadelphia 1893, s. *129-*138.

12 M.in. J. A. Geltzer, Decisions Detained: The Court's Embrace of Complexity in Guantanamo-Related Litigation, „BerkeleyJournal of International Law”2010, Vol.29, s.94; J. Hafetz, Calling the Government to Account: Habeas Corpus in the Aftermath of Boumediene, „Wayne Law Review” 2011, Vol. 57, s. 99; D. Mortlock, Definite Detention: The Scope of the President's Authority to Detain Enemy Combatants, „Harvard Law \& Policy Review” 2010, Vol. 4, s. 375; N. H. Nesbitt, Meeting Boumediene's Challenge: The Emergence of an Effective Habeas Jurisprudence and Obsolescence of New Detention Legislation, „Minnesota Law Review” 2010, Vol. 95, s. 244; T. L. Sparrow, Indefinite Detention after Boumediene: Judicial Trailblazing in Uncharted and Unfamiliar Territory, „Suffolk University Law Review” 2011, Vol. 44, s. 261.

13 R. M. Chesney, Who May be Held? Military Detention through the Habeas Lens, „Boston College Law Review" 2011, Vol. 52, s. 769.

14 S. I. Vladeck, The D.C. Circuit after Boumediene, „Seton Hall Law Review” 2011, Vol. 41, s. 1451.

15 B. Wittes, R. M. Chesney, L. Reynolds, The Emerging Law of Detention 2.0. The Guantánamo Habeas Cases as Lawmaking, Governance Studies at Brookings, Washington 2012, [online] http://www.broo kings.edu/ /media//files/reports/2011/5/guantanamo\%20wittes/05_guantanamo_wittes.pdf, 2 V 2013.

16 National Defense Authorization Act for FY 2012, Pub. L. No. 112-81, \$\$1021 et seq., 125 Stat. 1298, 1562 (2011). Zob. szerzej w części I niniejszego artykułu. 
tylko w zakresie, w jakim są one włączone do porządku prawnego USA. W przypadku norm traktatowych będzie to dotyczyć przepisów zawartych w umowach międzynarodowych stosowalnych bezpośrednio (self-executing) ${ }^{17}$, które nie pozostają w sprzeczności z Konstytucją ani później uchwalonymi ustawami ${ }^{18}$. Z kolei w zakresie norm prawa międzynarodowego zwyczajowego artykuł uwzględniać będzie jedynie te normy, o których włączeniu do prawa wewnętrznego można jednoznacznie stwierdzić w oparciu o orzecznictwo.

Artykuł poniższy koncentruje się na orzecznictwie Sądu Najwyższego USA oraz Sądu Apelacyjnego dla Okręgu Dystrykt Kolumbii, ze względu na szczególną rolę tego ostatniego w sprawach związanych z detencją wojskową ${ }^{19}$. Prawo dotyczące tego obszaru formulowane jest przede wszystkim w sprawach o habeas corpus wnoszonych przez osadzonych w Guantánamo ${ }^{20}$, w których właściwy geograficznie jest Sąd Dystryktowy dla Dystryktu Kolumbii ${ }^{21}$. Także Kongres wyraził preferencję na rzecz rozstrzygania spraw związanych ze stosowaniem detencji wojskowej przez Sąd Apelacyjny dla Okręgu Dystrykt Kolumbii ${ }^{22}$.

\section{PODSTAWA PRAWNA DETENCJI WOJSKOWEJ}

Administracja George’a W. Busha powoływała się na dwie wzajemnie niezależne, ale uzupełniające się podstawy prawne detencji wojskowej $j^{23}$. Pierwszą z nich była wspólna rezolucja izb Kongresu ${ }^{24}$ z 18 września 2001 r., upoważniająca prezydenta do uży-

17 Restatement of the Law, Third: Foreign Relations Law of the United States, Philadelphia 1987, \$111(3), (4), cmt. h (dalej: Restatement (Third) of Foreign Relations Law); C. A. Bradley, J. L. Goldsmith, Foreign Relations Law. Cases and Materials, New York 2009, s. 445-61.

18 W USA relacje między umowami międzynarodowymi a ustawami reguluje zasada lex posterior derogat legi priori. Zob. m.in. Head Money Cases, 112 U.S. 580 (1884); Whitney v. Robertson, 124 U.S. 190, 194 (1888); Breard v. Greene, 523 U.S. 371, 376 (1998); Restatement (Third) of Foreign Relations Law, $\$ 115$.

19 S. I. Vladeck, The D.C. Circuit..., s. 1452.

20 Zob. Al Maqaleh v. Gates, 605 F.3d 84 (D.C. Cir. 2010).

21 S. I. Vladeck, The D.C. Circuit..., s. 1452, przyp. 14; Boumediene v. Bush, 553 U.S. 723, 795-796 (2008).

22 Zob. np. Detainee Treatment Act of 2005 (Department of Defense Appropriations Act for FY 2006), $\$$ Pub. L. No. 109-148, Div. A, Title X, 119 Stat. 2680, 2739-44 (2005), 1005(e)(2)(A); 10 U.S.C. $\$ 950 \mathrm{~g}$.

23 J. S. Bybee, Re: The President's Power as Commander in Chief to Transfer Captured Terrorists to the Control and Custody of Foreign Nations, 26 Op. O.L.C., 2002 WL 34482991 (13 III 2002); tenże, Determination of Enemy Belligerency and Military Detention, 26 Op. O.L.C., 2002 WL 34482990 (8 VI 2002); J. C. Yoo, Applicability of 18 U.S.C. $\$ 4001$ (a) to Military Detention of United States Citizens, 26 Op. O.L.C., 2002 WL 34482988 (27 VI 2002); Brief for the Respondents, Hamdi v. Rumsfeld, Docket No. 03-6696, 542 U.S. 507 (2004), 29 III 2004, s. 13-22; Brief for the Respondents, Boumediene v. Bush, Nos. 06-1195, 06-1196, 553 U.S. 723 (2008), 9 X 2007, s. 62-67.

24 Wspólna rezolucja (joint resolution) w amerykańskiej praktyce ustrojowej ma pełną moc prawną ustawy i różni się od niej jedynie procedurą w Kongresie. House Rules and Manual, $112^{\text {th }}$ Congress, 
cia siły przeciwko krajom, organizacjom i osobom odpowiedzialnym za ataki z 11 września 2001 r., tzw. AUMF (Authorization for Use of Military Force) ${ }^{25}$. Drugą natomiast były uprawnienia prezydenta jako naczelnego dowódcy sił zbrojnych, wynikające wprost $\mathrm{z}$ art. II Konstytucji ${ }^{26}$. Administracja uważała, że z obu wymienionych podstaw prawnych wynika uprawnienie prezydenta do użycia siły zbrojnej do działań wojennych przeciwko Al-Kaidzie oraz powiązanym z nią organizacjom, w którym zawiera się prawo brania jeńców i więzienia ich do czasu zakończenia konfliktu ${ }^{27}$. Administracja Baracka Obamy to stanowisko podtrzymała tylko częściowo - w 2009 r., w memorandum przedstawionym w sprawie Hamlily $v$. Obama ${ }^{28}$, zrezygnowała ona z argumentu odwołującego się do pozaustawowych kompetencji prezydenta, powołując się tylko na AUMF $^{29}$. W 2011 r. interpretacja AUMF przedstawiana przez obie administracje została zaaprobowana przez Kongres sekcją 1021 ustawy autoryzującej programy budżetowe na obronę narodową na rok fiskalny $2012^{30}$.

Analizę stanowiska prawnego administracji należy rozpocząć od AUMF. Sekcja 2 rezolucji upoważnia prezydenta do użycia wszelkiej potrzebnej i odpowiedniej siły (all necessary and appropriate force) przeciwko krajom, organizacjom i osobom, które uzna on za odpowiedzialne za zaplanowanie, autoryzowanie i przeprowadzenie ataków terrorystycznych z 11 września $2001 \mathrm{r}$. lub za pomoc w ich przeprowadzeniu, a także za ochranianie takich osób i organizacji, w celu zapobieżenia wszelkim dalszym aktom terrorystycznym przeciwko Stanom Zjednoczonym ze strony takich krajów, organizacji i osób ${ }^{31}$. Przepis ten nie precyzuje wprost, że chodzi tu o użycie siły zbrojnej, ale wskazują na to liczne przesłanki. Po pierwsze, zarówno pełny, jak i skrócony tytuł rezolucji wspomina o użyciu siły zbrojnej. Po drugie, w praktyce konstytucyjnej rezolucja upoważniająca prezydenta do użycia siły zbrojnej jest przyjętą formą autoryzacji ze strony Kongresu dla konfliktów zbrojnych, w których Kongres nie chciał lub nie mógł formalnie wypowiedzieć wojny ${ }^{32}$. Po trzecie, sekcja 2(b) rezolucji stwierdza, iż stanowi ona ustawowe upoważnienie do użycia siły zbrojnej w rozumieniu War Powers Resolution

red. J. V. Sullivan, H. Doc. No. 111-157, $112^{\text {th }}$ Cong., $1^{\text {st }}$ Sess. (2012), §397; Bowsher v. Synar, 478 U.S. 714, 756 (1986).

25 AUMF (50 U.S.C. \$1541 note).

26 The President shall be commander in chief of the Army and Navy of the United States, and of the militia of the several states, when called into the actual service of the United States - U.S. Const., art. II, $\$ 2$.

27 B. Wittes, R. M. Chesney, L. Reynolds, The Emerging Law of Detention 2.0..., s. 14-18.

28 Respondents' Memorandum Regarding the Government's Detention Authority Relative to Detainees Held at Guantanamo Bay (Docket \# 1690), In re: Guantanamo Bay Detainee Litigation, Misc. No. 08-442 (TFH), 616 F.Supp.2d 63 (D.D.C. 2009), 13 III 2009 (Hamlily Brief).

29 Tamże, s. 1; zob. szerzej B. Wittes, R. M. Chesney, L. Reynolds, The Emerging Law of Detention 2.0..., s. 26.

30 National Defense Authorization Act for FY 2012, \$1021(a) (10 U.S.C. $\$ 801$ note).

31 AUMF, $₫ 2(\mathrm{a})$.

32 Zob. m.in. C. A. Bradley, J. L. Goldsmith, Congressional Authorization..., s. 2059-2060; J. K. Elsea, R. F. Grimmett, Declarations of War and Authorizations for the Use of Military Force. Historical Background and Legal Implications, CRS Report RL31133, Washington 2011, s. 8-19, 22-24. 
z 1973 r. $^{33}$ Taka interpretacja AUMF jest też zgodna z wykładnią przyjmowaną podczas prac legislacyjnych nad nią ${ }^{34}$.

Prawo amerykańskie rozróżnia dwa rodzaje konstrukcji prawnych upoważniających prezydenta do użycia siły: tzw. reżim wojny zupełnej (perfect lub complete war) oraz reżim wojny ograniczonej (imperfect lub limited war), w którym użycie siły jest ograniczone co do miejsc, celów lub sposobów ataku ${ }^{35}$. AUMF nie formułuje żadnych tego typu restrykcji wprost, określa jedynie (bardzo ogólnie) przeciwnika oraz cel użycia sity ${ }^{36}$. Pod tym względem bliższe jest sformułowaniom używanym przez Kongres przy rozpoczynaniu wojen zupełnych, w tym interwencji zbrojnych na dużą skalę (jak np. wietnamskiej czy obu irackich ${ }^{37}$. Za rozszerzającą wykładnią AUMF przemawia też tradycja takiej interpretacji sformułowania necessary and appropriate $\mathrm{w}$ amerykańskiej tradycji prawnej ${ }^{38}$ oraz wypowiedzi członków Kongresu padające podczas dyskusji nad AUMF w 2001 r. $^{39}$

AUMF nie jest jedynym potencjalnym źródłem kompetencji prezydenta do prowadzenia działań wojennych przeciwko organizacjom terrorystycznym odpowiedzialnym za ataki z 11 września 2001 r. Administracja George’a W. Busha powoływała się w tym względzie także na pozaustawowe kompetencje prezydenta wypływające wprost z Konstytucji ${ }^{40}$. Orzecznictwo ${ }^{41}$, ustawy ${ }^{42}$, opinie Urzędu Doradztwa Prawnego

33 War Powers Resolution, Pub. L. No. 93-148, § 5(b), 87 Stat. 555 (1973) (50 U.S.C. \$1544(b)).

34 D. Abramowitz, The President, the Congress, and Use of Force: Legal and Political Considerations in Authorizing Use of Force against International Terrorism, „Harvard International Law Journal” 2002, Vol. 43, s. 71; R. F. Grimmett, Authorization for Use of Military Force in Response to the 9/11 Attacks (P.L. 107-40). Legislative History, CRS Report for Congress RS22357, Washington 2006; 147 Congressional Record, $107^{\text {th }}$ Cong., $1^{\text {st }}$ Sess., 14 IX 2001, s. S9411-S9430, H5638-H5683.

35 Bas v. Tingy, 4 U.S. (4 Dall.) 37, 40 (1800) (Washington, J., seriatim); tamże, s. 43 (Chase, J., seriatim); Miller v. The Resolution, 2 U.S. (2 Dall.) 19, 21 (Ct. App. in Cases of Capture 1781). Zob. też K. L. Einspanier, Burlamaqui, the Constitution, and the Imperfect War on Terror, "Georgetown Law Journal" 2008, Vol. 96, s. 985, 988-998.

36 Tamże, s. 2078; M. S. Paulsen, Youngstown Goes to War, „Constitutional Commentary” 2002, Vol. 19, s. $215,252$.

37 C. A. Bradley, J. L. Goldsmith, Congressional Authorization..., s. 2062-2064, 2072-2083.

38 McCulloch v. Maryland, 17 U.S. (4 Wheat.) 316 (1819). Zob. też m.in. Madison-Hughes v. Shalala, 80 F.3d 1121, 1128 ( $6^{\text {th }}$ Cir. 1996); Texas Co. v. State ex rel. Coryell, 180 P.2d 631, 640, 198 Okla. 565 (1945).

39147 Congressional Record, $107^{\text {th }}$ Cong., $1^{\text {st }}$ Sess., 14 IX 2001, s. S9422 (Sen. Biden); tamże, s. H5662 (Rep. Davis); tamże, s. H5639 (Rep. Hyde and Lantos); tamże, s. H5646 (Rep. Schiff); tamże, s. H5649 (Rep. Spratt).

40 J. C. Yoo, The President's Constitutional Authority to Conduct Military Operations against Terrorists and Nations Supporting Them, 25 Op. O.L.C., 2001 WL 34726560 (25 IX 2001); Brief for the Respondents, Hamdi v. Rumsfeld, 542 U.S. 507 (2004), s. 13; Brief for the Respondents, Boumediene v. Bush, 553 U.S. 723 (2008), s. 66-67; D. Mortlock, Definite Detention..., s. 378.

41 The Amy Warwick (The Prize Cases), 67 U.S. (2 Black) 635, 668-669 (1863); United States v. Smith, 27 F.Cas. 1192, 1230 (C.C.D.N.Y. 1806) (No. 16,342) (Paterson, Circuit Justice); Mitchell v. Laird, 488 F.2d 611, 613 (D.C. Cir. 1973); Campbell v. Clinton, 203 F.3d 19, 27 (D.C. Cir. 2000) (Silberman, J., concurring).

42 War Powers Resolution, $\$ 2(\mathrm{c}), 50$ U.S.C. $\$ 1541(\mathrm{c})$. 
(OLC $)^{43}$ oraz badacze ${ }^{44}$ zgadzają się co do tego, że prezydent ma prawo do użycia siły zbrojnej w odpowiedzi na atak wymierzony w Stany Zjednoczone. Bardziej kontrowersyjna jest teza, że prezydent może też bez upoważnienia ustawowego rozpocząć działania wojenne wyprzedzające taki atak, aczkolwiek istnienie pewnych immanentnych uprawnień prezydenta do podejmowania działań w celu zapobiegania aktom terrorystycznym Kongres uznał w preambule AUMF ${ }^{45}$.

Administracja Baracka Obamy zrezygnowała z powoływania się na pozaustawowe uprawnienia prezydenta jako podstawy prawnej detencji wojskowej ${ }^{46}$. Wskazać można szereg przyczyn takiej decyzji. Po pierwsze, AUMF okazała się wystarczającym upoważnieniem dla działań egzekutywy. Po drugie, trwające wciąż kontrowersje prawne co do zakresu jednostronnych uprawnień egzekutywy do użycia siły bez upoważnienia ustawowego ${ }^{47}$ rzucałyby cień wątpliwości na wszelkie działania podjęte w oparciu o taką podstawę prawną. Przede wszystkim jednak wspomnieć trzeba o przesłankach politycznych: celem polityki prawnej administracji George’a W. Busha było promowanie szerokiej koncepcji prerogatyw urzędu Prezydenta ${ }^{48}$. Temu też służyło powoływanie się na pozaustawowe kompetencje do użycia siły ${ }^{49}$. Administracja Obamy przyjęła odmienne stanowisko, ze względu na odmienny pogląd na konstytucyjną pozycję egzekutywy ${ }^{50}$, ale też z powodu negatywnego odbioru argumentów poprzedników przez sądy, Kongres i opinię publiczną.

43 J. M. Harmon, Presidential Power to Use the Armed Forces Abroad without Statutory Authorization, 4A Op. O.L.C. 185, 186 (1980); J. C. Yoo, R. J. Delahunty, Authority for Use of Military Force to Combat Terrorist Activities within the United States, 25 Op. O.L.C., 2001 WL 36190674 (23 X 2001).

44 M. D. Ramsey, The Constitution's Text in Foreign Affairs, Cambridge (Mass.) 2007, s. 242; L. Henkin, Foreign Affairs and the United States Constitution, Oxford-New York 1996, s. 47-48; F. D. Wormuth, E. B. Firmage, To Chain the Dog of War. The War Power of Congress in History and Law, Urbana 1989, s. 22, 29; L. Fisher, Presidential War Power, Lawrence 2004, s. 7-10, 263.

45 Whereas, the President has authority under the Constitution to take action to deter and prevent acts of international terrorism against the United States - AUMF, preamble. Kongres odrzucil jednak proponowane przez egzekutywę sformułowanie tekstu rezolucji, które przyznawałoby prezydentowi prawo wyprzedzającego użycia siły w celu zapobieżenia aktom terroryzmu. D. Abramowitz, The President..., s. 73-74, 77-78.

46 H. H. Koh, Legal Adviser, U.S. Department of State, The Obama Administration and International Law, Annual Meeting of the American Society of International Law, Washington, 25 III 2010, [online] http://www.state.gov/s/l/releases/remarks/139119.htm, 22 V 2013.

47 Podsumowanie najważniejszych głosów w dyskusji nad zakresem uprawnień prezydenta do jednostronnego użycia siły przedstawiają m.in. J. E. Stromseth, Understanding Constitutional War Powers Today: Why Methodology Matters, „Yale Law Journal” 1996, Vol. 106, s. 845, 845-865, [online] http:// dx.doi.org/10.2307/797312; C. A. Bradley, J. L. Goldsmith, Foreign Relations Law..., s. 239-244; M. A. Zeisberg, War Powers. The Politics of Constitutional Authority, Princeton 2013, s. 1-53.

48 J. L. Goldsmith, The Terror Presidency. Law and Judgment inside the Bush Administration, New York 2007, s. 86-90.

49 J. O. McGinnis, Losing the Law War: The Bush Administration's Strategic Errors, „Georgia State University Law Review" 2008, Vol. 25, s. 377, 389.

50 B. Wittes, Klaidman Post \#1: Where that March 13 Brief Came From, Lawfare, 10 VI 2012, [online] http://www.lawfareblog.com/2012/06/klaidman-post-1-where-that-march-13-brief-came-from/, $25 \mathrm{~V} 2013$. 
Wywodząc legalność detencji wojskowej z prawa do użycia siły zbrojnej, administracja powoływała się na praktykę historyczną oraz zwyczajowe prawo wojny ${ }^{51}$. Branie jeńców stanowi element prowadzenia wojny od najdawniejszych czasów ${ }^{52}$, uznany przez „uniwersalną zgodę i praktykę" państw ${ }^{53}$, konwencje międzynarodowe ${ }^{54}$ oraz autorów traktujących o prawie międzynarodowym ${ }^{55}$. We współczesnym prawie wojny ma ono na celu uniemożliwienie pojmanym wrogom powrotu na pole bitwy lub podjęcia innych działań wymierzonych przeciwko stronom konfliktu ${ }^{56}$. W USA prawo takie uznają liczne decyzje sądowe ${ }^{57}$, ustawy ${ }^{58}$ oraz opinie prokuratorów generalnych ${ }^{59}$. Ponadto zauważyć należy, iż zazwyczaj uprawnienia prezydenta jako naczelnego dowódcy w konflikcie autoryzowanym przez Kongres są interpretowane szeroko ${ }^{60}$. Przesłanki te prze-

51 Zob. m.in. J. C. Yoo, Applicability..., s. *2-3; Brief for the Respondents, Hamdi v. Rumsfeld, 542 U.S. 507 (2004), s. 14-16; Brief for the Petitioner, Rumsfeld v. Padilla, No. 03-1027, 542 U.S. 426 (2004), 17 III 2004, s. 27-30.

52 A. Klein, B. Wittes, Preventive Detention in American Theory and Practice, „Harvard National Security Journal" 2011, Vol. 2, s. 85, 93-100; A. Rosas, The Legal Status of Prisoners of War. A Study in International Humanitarian Law Applicable in Armed Conflicts, Helsinki 1976, s. 44-45, Annales Academiae Scientiarum Fennicae. Dissertationes Humanarum Litterarum, 9; L. F. L. Oppenheim, International Law, t. 2: War and Neutrality, London 1906, s. 129-131.

53 Exparte Quirin, 317 U.S. 1, 30-31 (1942); Hamdi v. Rumsfeld, 542 U.S. 507, 518 (2004).

54 Zob. The Hague Convention (IV): Respecting the Laws and Customs of War on Land, Oct. 18, 1907, 36 Stat. 2277 (1907), Annex, art. 3; Geneva Convention Relative to the Treatment of Prisoners of War, July 27, 1929, 47 Stat. 2021 (1929), art. 1; Geneva Convention (III) Relative to the Treatment of Prisoners of War, Aug. 12, 1949, 6 U.S.T. 3316, T.I.A.S. No. 3364 (1949), art. 4, 21.

55 H. Grotius, The Rights of War and Peace (De iure belli ac pacis, libri tres; 1620), red. R. Tuck, lib. 3, ch. 7, Indianapolis 2005; C. van Bynkershoek, Quaestionum juris publici libri duo (1737), lib. 1, ch. 3, Oxford 1930, Classics of International Law, 14. Publications of the Carnegie Endowment for International Peace, Division of International Law; E. de Vattel, The Law of Nations, or, the Principles of Law of Nature (1758), red. B. Kapossy, R. Whatmore, lib. 3, ch. 8, \$148, Indianapolis 2008, Natural Law and Enlightenment Classics; F. Lieber, Instructions for the Government of Armies of the United States in the Field, U.S. War Dep't, General Order No. 100 (Apr. 24, 1863), Washington 1898, art. 15; T. Baty, J. H. Morgan, War. Its Conduct and Legal Results, London 1915, s. 172; Ch. Ch. Hyde, International Law, Chiefly as Interpreted and Applied by the United States, t. 2, \$655, Boston 1922, s. 300.

56 Handi v. Rumsfeld, 542 U.S. at 518-519; In re Territo, 156 F.2d 142, 149 (9 $9^{\text {th }}$ Cir. 1946); F. Lieber, Instructions..., art. 49 i nast., art. 75; W. Winthrop, Military Law and Precedents, Washington 1920, s. 788-789; In re Goering and Others (Major War Criminals Case), 13 Ann. Dig. 203, 41 Am. J. Int'l L. 172, I.M.T. (Nuremberg) 1946.

Moyer v. Peabody, 212 U. S. 78, 84-85 (1909); Ex parte Quirin, 317 U.S. 1, 28 (1942).

58 Zob. m.in. An Act for the Safe Keeping and Accommodation of Prisoners of War, July 6, 1812, $12^{\text {th }}$ Cong., $11^{\text {st }}$ Sess., ch. 128, 2 Stat. 777 (1812); 10 U.S.C. $\$ 956(5)$ (Pub. L. 98-525, Title XIV, Sec. 1401(b)(1), 98 Stat. 2614).

59 Zob. m.in. C. Lee, Treason, 1 Op. Att'y Gen. 84, 85 (1798); J. Speed, Reply of the Attorney General to the Resolution of the Senate Relative to the Prosecution of Jefferson Davis for Treason, $11 \mathrm{Op}$. Att'y Gen. 411 (1866).

60 Youngstown Sheet \& Tube Co. v. Sawyer, 343 U.S. 579, 645 (1952) (Jackson, J., concurring) (I should indulge the widest latitude of interpretation to sustain [the President's] exclusive function to command the instruments of national force, at least when turned against the outside world for the security of our society); Fleming v. Page, 50 U.S. (9 How.) 603, 61513 L.Ed. 276 (1850). 
mawiają za uznaniem, że upoważnienie do użycia siły zbrojnej pociąga za sobą prawo stosowania detencji wojskowej.

Z taką konkluzją w 2004 r. zgodziła się większość sędziów Sądu Najwyższego w sprawie Hamdi v. Rumsfeld ${ }^{61}$, rozstrzygając, czy AUMF zezwala na detencję obywatela amerykańskiego pojmanego w trakcie działań wojennych w Afganistanie. W opinii sędzi O'Connor czworo sędziów uznało, że więzienie wrogich kombatantów jest fundamentalnym elementem każdego konfliktu zbrojnego, więc mieści się w pojęciu „potrzebnej i odpowiedniej siły, do której użycia prezydent jest upoważniony ${ }^{62}$. Teza ta zyskała poparcie większości Sądu, gdyż zgodzili się z nią też sędziowie Thomas ${ }^{63}$ oraz Scalia i Stevens ${ }^{64}$. Jedynie sędziowie Souter i Ginsburg mieli wątpliwości co do legalności detencji wojskowej (z powodu nieprzyznania osadzonym statusu jeńców wojennych $)^{65}$.

Jakkolwiek Sąd Najwyższy w sprawie Hamdi v. Rumsfeld podkreślał wąski charakter swojej decyzji, to precedens ten właściwie rozstrzygnął dyskusję nad istnieniem podstawy prawnej detencji wojskowej (jednakże nie nad jej materialnoprawnym zakresem) ${ }^{66}$. Interpretacja AUMF przedstawiona w opiniach sędzi O'Connor i sędziego Thomasa została ponadto w 2011 r. explicite zatwierdzona przez Kongres w ustawie autoryzującej wydatki na obronę narodową na rok fiskalny 2012 (National Defense Authorization Act for FY 2012, NDAA) ${ }^{67}$. Decyzja ta była rezultatem dyskusji w Kongresie oraz wśród opinii publicznej na temat konieczności stworzenia nowych ustawowych ram dla reżimu detencji wojskowej ${ }^{68}$. Była ona motywowana m.in. przez opór wobec prezydenckich planów zamknięcia więzienia w Guantánamo, dążenie do uporządkowania prawa dotyczącego jeńców pojmanych podczas wojny z terroryzmem ${ }^{69}$ oraz głosy, że to nie sędziowie, a demokratycznie wybrany Kongres powinien określać, kto i na jakich warunkach może być osadzony jako wrogi kombatant ${ }^{70}$.

${ }_{61}$ Hamdi v. Rumsfeld, 542 U.S. 507 (2004).

62 Tamże, s. 518.

63 Tamże, s. 586-588 (Thomas, J., dissenting).

64 Tamże, s. 574, przyp. 5 (Scalia, J., dissenting).

65 Tamże, s. 548-551 (Souter, J., concurring in part, dissenting in part, and concurring in the judgment).

66 Al-Marri v. Pucciarelli, 534 F.3d 213, 228-229 (4 $4^{\text {th }}$ Cir. 2008) (Motz, concurring in judgment); tamże, s. 257-58 (Traxler, J., concurring in judgment); tamże, s. 283-85 (Williams, C.J., concurring in part and dissenting in part); Al-Bihani v. Obama, 590 F.3d 866, 872 (D.C. Cir. 2010); Khan v. Obama, 741 F.Supp.2d 1 (D.D.C. 2010).

67 Pub. L. 112-81, \$1021(a), 125 Stat. 1298, 1562 (10 U.S.C. $\$ 801$ note).

68 Zob. szerzej M. J. Garcia [i in.], Closing the Guantanamo Detention Center. Legal Issues, CRS Report R40139, Washington 2011; R. M. Chesney, Who May be Held?..., s. 855.

69 Zob. szerzej W. E. Kuhn, The Terrorist Detention Review Reform Act: Detention Policy and Political Reality, „Seton Hall Legislative Journal” 2011, Vol. 35, s. 221; R. M. Chesney, Who May be Held?..., s. 864-865.

70 M.in. J. B. Bellinger III, A Counterterrorism Law in Need of Updating, „Washington Post” 2010, 26 XI, [online] http://www.washingtonpost.com/wp-dyn/content/article/2010/11/25/AR2010 112503116.html, 18 V 2013. 
Pierwsze projekty prawa kodyfikującego normy detencji wojskowej zgłaszane były jeszcze w 110. i 111. Kongresie ${ }^{71}$, ale szanse ich powodzenia znacząco wzrosły w 112. Kongresie, gdy republikanie zdobyli większość w Izbie Reprezentantów. 9 marca 2011 r. projekt ustawy regulującej postępowanie z osadzonymi w Guantánamo przedstawił w Izbie przewodniczący Komisji ds. Sił Zbrojnych kongresman Buck McKeon $(\mathrm{R}-\mathrm{CA} 25)^{72}$. Sekcja 7 ustawy McKeona zawierała reafirmację AUMF z 2001 r., jak również wprost autoryzowała detencję wojskową oraz definiowała podległe jej osoby. Podobnej treści przepisy znalazły się w projekcie zgłoszonym dzień później przez senatora Johna McCaina ${ }^{73}$. Żaden z tych projektów nie wyszedł poza etap prac komisji, ale ich postanowienia zostały włączone do komisyjnego projektu dorocznej ustawy autoryzacyjnej dla Departamentu Obrony ${ }^{74}$. Sekcja 1034 projektu NDAA potwierdzała ciągłe obowiązywanie AUMF i definiowała jej zakres zgodnie z interpretacją przedstawioną przez egzekutywę w sprawie Hamlily. Bardzo podobne uregulowanie, chociaż odnoszące się jedynie do zakresu detencji wojskowej, znalazło się w wersji senackiej projektu ${ }^{75}$. Obie wersje, podobnie jak raport komisji konferencyjnej, explicite potwierdzały, że AUMF zawiera w sobie upoważnienie do stosowania detencji wojskowej wobec wrogich kombatantów, i tak też stanowił ostateczny tekst ustawy ${ }^{76}$.

\section{KONSTYTUCYJNOŚĆ AUMF I NDAA}

Pomimo przedstawionych powyżej przesłanek część komentatorów oraz organizacji poza-i międzyrządowych wciąż kwestionuje legalność detencji wojskowej, jak również całej prawnej konstrukcji „wojny z terroryzmem” opartej na reżimie prawnym konflik-

71 Zob. m.in. Enemy Combatant Detention Review Act of 2008, $110^{\text {th }}$ Cong., S. 3401 (2008); Terrorist Detention Review Reform Act, $111^{\text {th }}$ Cong., S. 3707 (2010); Enemy Belligerent Interrogation, Detention, and Prosecution Act, $111^{\text {th }}$ Cong., S. 3081 (2010); $111^{\text {th }}$ Cong., H.R. 4892 (2010). Zob. też J. Weingarten, The Detention of Enemy Combatants Act, „Harvard Journal on Legislation” 2006, Vol. 43, s. 181.

72 Detainee Security Act of 2011, 112 $2^{\text {th }}$ Cong., H.R. 968 (2011). Zob. też House Armed Services Committee Press Release, 8 III 2011, [online] http://armedservices.house.gov/index.cfm/files/serve ?File_id=b8435f9f-9a0b-4608-a410-de8ca8dfa602, 19 V 2013.

73 Military Detainee Procedures Improvement Act of 2011, $112^{\text {th }}$ Cong., S. 551 (2011), $\$ 2$.

$74112^{\text {th }}$ Cong., H.R. 1540, Chairman's Mark, Title X, Subtitle D, 11 V 2011, [online] http://armedse rvices.house.gov/.cfm//?File_id=61e9d0d1-581b-4204-ba0e-f601878bc710, 19 V 2013.

$75112^{\text {th }}$ Cong., S. 1867 (engrossed in the Senate), $\$ 1031$. W kwestii szczegółowego porównania obu wersji zob. B. Wittes, House-Senate Side-by-Side of NDAA Provisions: Part I, Lawfare, 7 XII 2011, [online] http://www.lawfareblog.com/2011/12/house-senate-side-by-side-of-ndaa-provisions-part$-\mathrm{i} /, 21 \mathrm{~V} 2013$.

76 NDAA, $\$ 1021(\mathrm{a})$. Co interesujące, jakkolwiek NDAA kodyfikowało stanowisko administracji z Hamlily Brief, ta ostatnia krytycznie odniosła się do projektu reafirmacji AUMF, początkowo nawet grożąc wetem. Zob. Executive Office of the President, Statement of Administration Policy on H.R. 1540, 24 V 2011, [online] http://www.whitehouse.gov/sites/default/files/omb/legislative/sap/ 112/saphr1540r_20110524.pdf, 21 V 2013. 
tu zbrojnego ${ }^{77}$. U podstaw tego sporu leży fakt, iż konflikt z Al-Kaidą jest zasadniczo odmienny od znacznej większości wcześniejszych konfliktów zbrojnych prowadzonych przez Stany Zjednoczone: przeciwnik nie ma atrybutów państwa ani regularnych sił zbrojnych, wrodzy kombatanci ukrywają się wśród ludności cywilnej i są obywatelami państw neutralnych lub sojuszniczych ${ }^{78}$, konflikt ma charakter globalny i prowadzony jest również na terytorium państw neutralnych ${ }^{79}$, środki militarne stosowane są zamiennie z cywilnymi działaniami antyterrorystycznymi i wywiadowczymi ${ }^{80}$, wreszcie sam terroryzm jeszcze nie tak dawno traktowany był (a przez dużą część sojuszników USA nadal jest) jako problem wymagający odpowiedzi przy użyciu środków karnych, a nie wojskowych ${ }^{81}$.

Podstawowym argumentem za konstytucyjnością konstrukcji prawnej „wojny z terroryzmem" jest stanowisko władz politycznych wyrażone w AUMF ${ }^{82}$. Rozstrzygnięcia sądowe wskazują, iż decyzja władz politycznych o istnieniu stanu wojny jest ostateczna i wiążąca dla władzy sądowniczej ${ }^{83}$. Przemawiają za tym zarówno argumenty strukturalne, jak i funkcjonalne. Kompetencję wypowiadania wojny Konstytucja powierza Kongresowi ${ }^{84}$, a nie sądom. Ponadto Konstytucja zostata zaprojektowana tak, by

Zob. m.in. S. D. Gorman, In the Wake of Tragedy: The Citizens Cry Out for War, but Can the United States Legally Declare War on Terrorism?, „Penn State International Law Review” 2003, Vol. 21, s. 669, 674-678; J. J. Paust, War and Enemy Status after 9/11: Attacks on the Laws of War, „Yale Journal of International Law" 2003, Vol. 28, s. 325; Brief of Amici Curiae International Law Professors Listed Herein in Support of Petitioner, Hamdan v. Rumsfeld, No. 05-184, 548 U.S. 557 (U.S. 2006), 5 I 2006, przyp. 2; J. Cerone, Misplaced Reliance on the "Law of War”, „New England Journal of International and Comparative Law" 2007, Vol. 14, s. 57.

78 R. M. Chesney, J. L. Goldsmith, Terrorism and the Convergence of Criminal and Military Detention Models, „Stanford Law Review” 2008, Vol. 60, s. 1079, 1099-1100; C. A. Bradley, J. L. Goldsmith, Congressional Authorization..., s. 2049.

79 Transcript of Oral Argument, Hamdi v. Rumsfeld, No. 03-6696, 542 U.S. 507 (2004), 28 IV 2004, s. 21-22.

80 J. L. Goldsmith, Terror Presidency..., s. 106.

81 R. M. Chesney, J. L. Goldsmith, Terrorism and the Convergence..., s. 1096-1100; J. L. Goldsmith, Terror Presidency..., s. 102-106. Zaznaczyć należy, że jeszcze przed 2001 r. model militarnej odpowiedzi na międzynarodowy terroryzm był obecny w polityce antyterrorystycznej USA. Zob. Antiterrorism and Effective Death Penalty Act of 1996, Pub. L. No. 104-132, 110 Stat. 1214 (1996), § 324(4); J. Lobel, The Use of Force to Respond to Terrorist Attacks: The Bombing of Sudan and Afghanistan, „Yale Journal of International Law" 1999, Vol. 24, s. 537; R. Wedgwood, Responding to Terrorism: The Strikes against bin Laden, „Yale Journal of International Law” 1999, Vol. 24, s. 559.

82 P. F. Philbin, Legality of the Use of Military Commissions to Try Terrorists, 25 Op. O.L.C., 2001 WL 36175681 (6 XI 2001); C. A. Bradley, J. L. Goldsmith, Congressional Authorization..., s. 2070-2071 .

83 The Three Friends, 166 U.S. 1, 63 (1897); United States v. 129 Packages, 27 F.Cas. 284, 288 (C.C.E.D.Mo. 1806) (No. 15,941); Hamilton v. McClaughry, 136 F. 445, 449 (C.C.D. Kan. 1905); The Ambrose Light, 25 F. 408, 412 (S.D.N.Y. 1885); In re Wulzen, 235 F. 362, 365 (S.D. Ohio 1916); Verano v. De Angelis Coal Co., 41 F.Supp. 954 (M.D. Pa. 1941); Sutton v. Tiller, 46 Tenn. 593, 98 Am.Dec. 471, 1869 WL 2594 (1869).

84 U.S. Const., art. I, $\$ 8$, cl. 11. 
przetrwać wieki i mieć zastosowanie w różnych sytuacjach ${ }^{85}$, a w żadnej dziedzinie jej elastyczność nie jest tak niezbędna, jak w odpowiedzi na zagrożenia dla bezpieczeństwa narodowego ${ }^{86}$. Uznając ten fakt, sądy i doktryna wielokrotnie podkreślały szeroki charakter kompetencji władz federalnych w zakresie prowadzenia wojny ${ }^{87}$. Przemawia on zdecydowanie przeciwko temu, by odmawiać Kongresowi prawa użycia siły zbrojnej wobec zagrożenia terrorystycznego, którego twórcy Konstytucji nie mogli wprost przewidzieć w 1789 r. Można oczywiście spierać się o to, czy taka odpowiedź jest uzasadniona, ale ocenę tej materii Konstytucja powierza władzom politycznym. Skala ataków z 11 września, bliższa konfliktowi zbrojnemu niż zwykłemu aktowi kryminalne$\mathrm{mu}^{88}$, jak również zewnętrzny charakter zagrożenia, uniemożliwiający jego eliminację na drodze policyjno-sądowej ${ }^{89}$, wydają się dostatecznymi przesłankami, by Kongres mógł odpowiedzieć twierdząco na to pytanie.

Nie jest też do końca prawdziwe stwierdzenie, że wojna z terroryzmem jest diametralnie odmienna od wcześniejszych konfliktów. Praktyka konstytucyjna bogata jest w precedensy dotyczące niekonwencjonalnych wojen. Już w 1800 r., w sprawie Bas v. Tingy ${ }^{90}$, Sąd Najwyższy uznał istnienie wojen formalnie niewypowiedzianych. Z kolei w 1863 r., w sprawie The Amy Warwick" ${ }^{91}$, Sąd przyznat, iż konflikt zbrojny ze Stanami Skonfederowanymi (których USA nigdy nie uznały za państwo, ale traktowały je jako powstańców ${ }^{92}$ ) jest jednak wojną w rozumieniu Konstytucji ${ }^{93}$. Sąd sformułował wówczas wielokrotnie cytowaną w późniejszym orzecznictwie ${ }^{94}$ definicję wojny, dostatecznie pojemną, by objąć także konflikt z organizacjami terrorystycznymi: wojna jest stanem, w którym kraj dochodzi swoich praw przy pomocy

85 McCulloch v. Maryland, 17 U.S. (4 Wheat.) 316, 415 (1819) ([The Constitution was] intended to endure for ages to come, and consequently, to be adapted to the various crises of human affairs).

86 A. Hamilton, The Federalist No. 23 (1788), [w:] The Federalist, red. G. W. Carey, J. McClellan, Indianapolis 2001, s. 112, 113 (The circumstances that endanger the safety of nations are infinite; and for this reason no constitutional shackles can wisely be imposed on the power to which the care of it is committed); tenże, The Federalist No. 34 (1788), [w:] The Federalist, s. 162, 163-164.

87 Hirabayashi v. United States, 320 U.S. 81, 93 (1943); Spaulding v. Douglas Aircraft Co., 154 F.2d 419 (9 ${ }^{\text {th }}$ Cir. 1946); L. Henkin, Foreign Affairs..., s. 67; B. N. Hollander, The President and Congress Operational Control of the Armed Forces, „Military Law Review” 1965, Vol. 27, s. 49, 55.

P. F. Philbin, Legality..., s. *24; C. A. Bradley, J. L. Goldsmith, Congressional Authorization..., s. 2068. Zob. też D. Jinks, September 11 and the Laws of War, „Yale Journal of International Law” 2003, Vol. 28, s. 1.

R. M. Chesney, J. L. Goldsmith, Terrorism and the Convergence..., s. 1096-1097. 4 U.S. (4 Dall.) 37 (1800). 12 Stat. 1258 (15 IV 1861).

The Amy Warwick, 67 U.S. at 666 ([I]t is not necessary to constitute war, that both parties should be acknowledged as independent nations or sovereign States).

94 Zob. m.in. Pan Am. World Airways, Inc. v. Aetna Casualty \& Surety Co., 505 F.2d 989, 1012 (2 $2^{\text {nd }}$ Cir. 1974); Campbell v. Clinton, 203 F.3d 19, 38 (D.C. Cir. 2000) (Tatel, J., concurring); Hamilton v. McClaughry, 136 F. 445 (C.C.D. Kan. 1905); In re Wulzen, 235 F. 362, 365 (S.D. Ohio 1916). 
sity ${ }^{95}$. Z kolei w sprawie Hamilton v. McClaughry ${ }^{96}$ Sąd Okręgowy dla Dystryktu Kansas uznał, iż interwencja zbrojna w Chinach przeciwko zagrażającemu misjom dyplomatycznym powstaniu bokserów miała charakter wojny, chociaż buntownicy chińscy nie mieli atrybutów państwowości (nawet de facto) ${ }^{97}$. Natomiast w w sprawach Marks v. United States ${ }^{98}$ oraz Montoya v. United States ${ }^{99}$ Sąd Najwyższy określił mianem wojen starcia zbrojne z Indianami, jakkolwiek ci ostatni nie mają atrybutów suwerenności, ale są zależnymi ludami wewnętrznymi ${ }^{100}$. Wreszcie wspomnieć należy o interpretacji określenia „wojna” w kontekście prawa karnego definiującego zbrodnię zdrady stanu ${ }^{101}$. W common law wszelka bezprawna zbrojna przemoc mająca na celu wywołanie rezultatów natury publicznej i politycznej na terenie kraju stanowiła akt wojny przeciwko Koronie ${ }^{102}$. Interpretacja ta została przyjęta również przez sądy amerykańskie w pierwszych latach istnienia Unii ${ }^{103}$. Wreszcie w $1999 \mathrm{r}$. Sąd Apelacyjny dla Drugiego Okręgu uznał, że członkowie grupy terrorystycznej, która w 1993 r. dokonała nieudanego zamachu na nowojorskie WTC i planowała kolejne ataki, są winni konspiracji mającej na celu prowadzenie wojny przeciwko Stanom Zjednoczonym ${ }^{104}$.

Z praktyki konstytucyjnej i orzecznictwa wynika zatem jednoznacznie, że koncepcja wojny w amerykańskim prawie konstytucyjnym jest wysoce elastyczna. Jakkolwiek żaden cytowany precedens nie odnosi się wprost do konfliktu z organizacją terrorystyczną, to uznanie takiego konfliktu za wojnę można potraktować jako logiczne rozszerzenie tych precedensów na nową sytuację faktyczną. W połączeniu z podo-

95 The Amy Warwick, 67 U.S. at 666 (War has been well defined to be, "That state in which a nation prosecutes its right by force"). Definicja ta pochodzi z: E. de Vattel, The Law of Nations..., lib. 3, ch. 1, $\$ 1$, s. 469.

96 Hamilton v. McClaughry, 136 F. 445 (C.C.D. Kan. 1905).

97 Tamże, s. 449-450.

98 Marks v. United States, 161 U.S. 297 (1896).

99 Montoya $v$. United States, 180 U.S. 261 (1901).

100 Cherokee Nation v. Georgia, 30 U.S. (5 Pet.) 1, 17, 8 L.Ed. 25 (1831). W kwestii wojen indiańskich zob. też B. F. Butler, Existence of War with the Seminoles, 3 Op. Att'y Gen. 307 (1838); A. T. Akerman, Unlawful Traffic with Indians, 13 Op. Att'y Gen. 470, 471 (1871); G. H. Williams, The Modoc Indian Prisoners, 14 Op. Att'y Gen. 249 (1873); F. D. Wormuth, E. B. Firmage, To Chain the Dog of War..., s. 125-129; E. J. Wallach, Partisans, Pirates, and Pancho Villa: How International and National Law Handled Non-State Fighters in the "Good Old Days" before 1949 and that Approach's Applicability to the "War on Terror”, „Emory International Law Review” 2010, Vol. 24, s. 549, 581-584.

101 Zob. Statute of Treasons of 1351 (A Declaration which Offences shall be adjudged Treason), 25 Edw. III st. 5 ch. 2 (1351); U.S. Const., art. III, $₫ 3$; An Act for the Punishment of Certain Crimes against the United States, Apr. 30, 1790, $1^{\text {st }}$ Cong., $2^{\text {nd }}$ Sess., ch. 9, 1 Stat. 112 (1790); 18 U.S.C. $\$ 2381$.

102 W. Hawkins, A Treatise of the Pleas of the Crown (1716), red. J. Curwood, London 1824, $\$ \$ 23,25$, Making of Modern Law; M. Hale, Historia placitorum coronae. The History of the Pleas of the Crown (1736), red. S. Emlyn, E. Ingersoll, W. A. Stokes, Philadelphia 1847, s. 131 i nast.; W. Blackstone, Commentaries..., t. 2, s. ${ }^{*} 81-* 82$.

103 Case of Fries, 9 F.Cas. 826 (C.C.D.Pa. 1799) (No. 5126) (Iredell, Circuit Justice).

104 United States v. Rahman, 189 F.3d 88, 123 (2 $2^{\text {nd }}$ Cir. 1999). 
bieństwami między wojną z terroryzmem a konwencjonalnymi wojnami ${ }^{105}$ oraz wspomnianym wyżej wymogiem daleko posuniętej deferencji wobec decyzji władz politycznych przemawia to zdecydowanie za uznaniem konstytucyjności prawa do użycia siły zbrojnej przeciw organizacjom terrorystycznym ${ }^{106}$.

\section{DETENCJA WOJSKOWA A KONSTYTUCYJNE GWARANCJE INDYWIDUALNYCH PRAW I WOLNOŚCI}

Pierwsze osiem poprawek do Konstytucji Stanów Zjednoczonych, często określane jako Karta praw, gwarantuje ochronę praw i wolności jednostek przed naruszeniami ze strony rządu federalnego ${ }^{107}$. Dla rozważań nad legalnością detencji wojskowej największe znaczenie z nich ma Piąta poprawka, stanowiąca m.in., że nikt nie może być pozbawiony życia, wolności ani własności bez należytej procedury prawnej (due process of law $)^{108}$. Klauzula ta wywodzi się z rozdz. 29 Magna Carty ${ }^{109} \mathrm{i}$ tradycji common law, chroniącej poddanych przed arbitralnym pozbawieniem wolności lub majątku ${ }^{110}$. W prawie amerykańskim nabrała ona dodatkowego znaczenia, gdyż ogranicza władzę nie tylko egzekutywy, ale i legislatury ${ }^{111}$.

W przeciwieństwie do niektórych innych konstytucyjnych gwarancji praw i wolności ${ }^{112}$ Piąta poprawka ochrania „osoby”, a nie tylko obywateli ${ }^{113}$. Od dawna nie podlega wątpliwościom, że zawarte w niej gwarancje, zarówno materialne, jak i proceduralne, chronią więc obcokrajowców przebywających w USA ${ }^{114}$. Jakkolwiek niektóre decyzje

105 C. A. Bradley, J. L. Goldsmith, Congressional Authorization..., s. 2068.

106 Sąd Najwyższy nie odniósł się wprost do możliwości istnienia konfliktu zbrojnego z Al-Kaidą, ale zaakceptował taką konstrukcję prawną w swej opinii w sprawie Hamdan v. Rumsfeld, 548 U.S. 557, 629 (2006) (Stevens, J., for the Court), 646 (Breyer, J., concurring), 718-719 (Thomas, J., dissenting).

107 Barron v. Baltimore, 32 U.S. (7 Pet.) 243 (1833).

108 U.S. Const., $5^{\text {th }}$ Amend. (Due Process Clause).

109 Magna Carta, 9 Hen. III (1225), ch. 29.

110 Zob. ogólnie E. Coke, Institutes of the Laws of England, in Four Parts (1628-1644), London 1794-1797, pt. II, s. 45-57; W. Blackstone, Commentaries..., t. 1, s. ${ }^{*} 134-136$; J. H. Killian, G. A. Costello, K. R. Thomas [i in.], The Constitution of the United States of America. Analysis and Interpretation. Analysis of Cases Decided by the Supreme Court of the United States to June 28, 2002, Washington 2004, s. 1434-1436, Senate Documents, 108-17.

111 Hurtado v. California, 110 U.S. 516, 532 (1884); Bank of Columbia v. Okely, 17 U.S. (4 Wheat.) 235, 244 (1819).

112 Zob. np. U.S. Const., $14^{\text {th }}$ Amend., $\$ 1$ (No state shall make or enforce any law which shall abridge the privileges or immunities of citizens of the United States).

113 U.S. Const., $5^{\text {th }}$ Amend. (No person shall [...] be deprived of life, liberty, or property, without due process of law).

114 Yick Wo v. Hopkins, 118 U.S. 356, 369 (1886) (dictum); Wong Wing v. United States, 163 U.S. 228 (1896); Bridges v. Wixon, 326 U.S. 135, 161 (1945) (Murphy, J., concurring); Mathews v. Diaz, 426 U.S. 67, 77 (1976); Zadvydas v. Davis, 533 U.S. 678, 693-694 (2001). 
Sądu Najwyższego sugerowały w dicta, że Piąta poprawka może nie mieć zastosowania do wrogich kombatantów ${ }^{115}$, to współczesne orzecznictwo nie przyjęło nawet tego ograniczenia ${ }^{116}$.

Przytoczone powyżej decyzje dotyczą jednak osób przebywających na terytorium USA $^{117}$. Eksterytorialne zastosowanie unormowań Karty praw jest o wiele bardziej problematyczne ${ }^{118}$. Wczesne amerykańskie prawo konstytucyjne całkowicie je wykluczało $^{119}$. W 1957 r. w sprawie Reid v. Covert ${ }^{120}$ Sąd Najwyższy uchylił jednak orzeczenie Ross, uznając, iż względem własnych obywateli rząd federalny poza granicami USA nie może działać inaczej niż w zgodzie z konstytucyjnymi ograniczeniami ${ }^{121}$. Jednak orzecznictwo sądowe ogranicza eksterytorialne zastosowanie konstytucyjnych gwarancji praw i wolności do obywateli ${ }^{122}$, ewentualnie obcokrajowców mających kontakty jurysdykcyjne ze Stanami Zjednoczonymi ${ }^{123}$. Obcokrajowcy pojmani i osadzeni za granicą nie mogą więc powoływać się na ochronę Piątej poprawki (aczkolwiek przysługuje im przywilej habeas corpus ${ }^{124}$ ).

Szczególnie skomplikowana jest sytuacja prawna jeńców osadzonych w bazie Guantánamo $^{125}$, gdyż powstaje problem, czy miejsce to należy uznawać za część tery-

11 Zob. m.in. In re Yamashita, 327 U.S. 1 (1946); Johnson v. Eisentrager, 339 U.S. 763, 771-775 (1950); Colepaugh v. Looney, 235 F.2d 429 (10 th $^{\text {th }}$ Cir. 1956); ale por. Ex parte Quirin, 317 U.S. 1, 38-46 (1942).

116 Zob. m.in. Hamdi v. Rumsfeld, 542 U.S. 507, 524 et seq. (2004).

117 Johnson v. Eisentrager, 339 U.S. 763, 771 (1950) ([I]n extending constitutional protections beyond the citizenry, the Court has been at pains to point out that it was the alien's presence within its territorial jurisdiction that gave the Judiciary power to act).

118 Zob. szerzej m.in. R. D. Rotunda, J. E. Nowak, Treatise on Constitutional Law. Substance and Procedure, St. Paul 2007, \$ 6.2(e)(ii); M. D. Falkoff, R. Knowles, Bagram, Boumediene, and Limited Government, „DePaul Law Review” 2010, Vol. 59, s. 851, 871-879; C. I. Keitner, Rights beyond Borders, „Yale Journal of International Law" 2011, Vol. 36, s. 55, 71-81.

119 Ross v. McIntyre, 140 U.S. 453, 464 (1891).

120 Reid v. Covert, 354 U.S. 1 (1957).

121 Tamże, s. 5-6 (Black, J., for plurality) (The United States is entirely a creature of the Constitution. Its power and authority have no other source. It can only act in accordance with all the limitations imposed by the Constitution).

122 Johnson v. Eisentrager, 339 U.S. 763, 784 (1950); United States v. Verdugo-Urquidez, 494 U.S. 259 (1990); Zadvydas v. Davis, 533 U.S. 678, 693 (2001); Jifry v. FAA, 370 F.3d 1174, 1182 (D.C. Cir. 2004); 32 County Sovereignty Comm. v. Dep't of State, 292 F.3d 797, 799 (D.C. Cir. 2002); Harbury v. Deutch, 233 F.3d 596, 603-604 (D.C. Cir. 2000), rev'd on other grounds sub nom. Christopher v. Harbury, 536 U.S. 403 (2002); People's Mojahedin Org. of Iran v. U.S. Dep't of State, 182 F.3d 17, 22 (D.C. Cir. 1999).

123 United States v. Verdugo-Urquidez, 494 U.S. at 271. Zob. też Plyler v. Doe, 457 U.S. 202, 211-212 (1982); Russian Volunteer Fleet v. United States, 282 U.S. 481, 489 (1931); National Council of Resistance of Iran v. Albright, 251 F.3d 192, 201 (D.C. Cir. 2001).

124 Zob. B. L. Garrett, Habeas Corpus and Due Process, „Cornell Law Review” 2012, Vol. 98, s. 47.

125 Zob. J. A. Geltzer, Of Suspension, Due Process, and Guantanamo: The Reach of the Fifth Amendment after Boumediene and the Relationship between Habeas Corpus and Due Process, "University of Pennsylvania Journal of Constitutional Law" 2012, Vol. 14, s. 719. 
torium Stanów Zjednoczonych ${ }^{126}$. Stanowisko formalistyczne uznaje, że nie: Stany Zjednoczone dzierżawią bazę od Kuby ${ }^{127}$, zaś umowa dzierżawy z 1903 r. wprost stanowi, iż Kuba zachowuje suwerenność nad obszarem bazy ${ }^{128}$. Ponadto orzecznictwo uznaje, że kwestię określania zasięgu suwerennego terytorium USA Konstytucja powierza wyłącznie władzom politycznym ${ }^{129}$, zaś w 2005 r. Kongres ustawowo potwierdził, iż nie uważa bazy za część Stanów Zjednoczonych ${ }^{130}$. Jednak zwolennicy stanowiska funkcjonalistycznego wskazują, że USA sprawują zupełną i nieograniczoną jurysdykcję nad bazą, przez co jej praktyczny status nie różni się istotnie od terytoriów należących do Stanów Zjednoczonych ${ }^{131}$.

Sąd Najwyższy po raz pierwszy odniósł się do terytorialnego statusu bazy Guantánamo w 2004 r., w sprawie Rasul v. Bush ${ }^{132}$. Sąd uznał wówczas obecność więźnia w granicach jurysdykcji terytorialnej sądu za niekonieczną do wydania writ of habe-

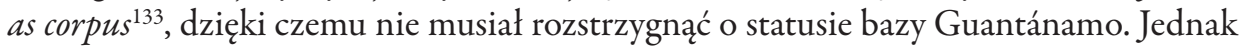
zarówno sędzia Stevens w dicta ${ }^{134}$, jak i sędzia Kennedy w jednej z opinii odrębnych ${ }^{135}$ przychylali się do stanowiska funkcjonalistycznego. W odpowiedzi na orzeczenie Rasul Kongres ustawowo wyłączył jurysdykcję sądów federalnych w sprawach o habeas wniesionych przez jeńców z Guantánamo ${ }^{136}$, przez co sprawa wróciła przed Sąd Najwyższy. W 2008 r. w sprawie Boumediene v. Bush stwierdził on, iż osadzonym w Guantánamo przysługuje konstytucyjne prawo do habeas corpus ${ }^{137}$. Sąd uznał bazę za część funkcjonalnie rozumianego terytorium USA ${ }^{138}$, przynajmniej w świetle historycznej praktyki

126 Spór ten powstal jeszcze przed 2001 r. na gruncie prawa imigracyjnego. Cuban American Bar Ass'n, Inc. v. Christopher, 43 F.3d 1412, 1424-1425 (11 ${ }^{\text {th }}$ Cir. 1995) i Haitian Centers Council, Inc. v. McNary, 969 F.2d 1326 ( $2^{\text {nd }}$ Cir. 1992), vacated as moot sub nom. Sale v. Haitian Centers Council, 509 U.S. 918 (1993).

127 Lease to the United States by the Government of Cuba of Certain Areas of Land and Water for Naval or Coaling Stations in Guantanamo and Bahia Honda, July 2, 1903, Treaty Series No. 426 (1903).

128 Agreement between the United States and Cuba for the Lease of Lands for Coaling and Naval Stations, Feb. 23, 1903, Treaty Series No. 418 (1903), art. III.

129 Jones v. United States, 137 U.S. 202 (1890); Vermilya-Brown Co. v. Connell, 335 U.S. 377, 380 (1948).

130 Detainee Treatment Act of 2005, $\$ 1005$ (g)

131 Agreement between the United States and Cuba for the Lease of Lands..., art. III; Rasul v. Bush, 542 U.S. 466, 487 (2004) (Kennedy, J., concurring); Boumediene v. Bush, 553 U.S. 723, 764-765 (2008). Zob. też Treaty Defining Relations with Cuba, May 29, 1934, 48 Stat. 1683, Treaty Series No. 866 (1934), art. III.

132 Rasul v. Bush, 542 U.S. 466 (2004).

133 Rasul v. Bush, 542 U.S. at 478-479, w oparciu o Braden v. 30th Judicial Circuit Court of Kentucky, 410 U.S. 484 (1973).

134 Rasul v. Bush, 542 U.S. at 480-483.

135 Tamże, s. 487 (Kennedy, J., concurring).

136 Detainee Treatment Act of 2005, $\$ 1005$ (e)(1); Military Commissions Act of 2006, Pub. L. No. 109-366, $\S 7(\mathrm{a})(1), 120$ Stat. 2600 (2006).

137 Boumediene v. Bush, 553 U.S. 723 (2008).

138 Tamże, s. 753-771. 
brytyjskiej, zgodnie z którą habeas był dostępny również na terenie niektórych posiadłości Korony poza granicami królestwa ${ }^{139}$.

Sąd w sprawie Boumediene oparł swoją decyzję wyłącznie na art. I $\$ 9$ Konstytucji, zakazującym zawieszania habeas corpus poza wypadkami inwazji lub rebeliii ${ }^{140}$, zaś nie odniósł się do problemu zastosowania Piątej poprawki w Guantánamo ${ }^{141}$. Część komentatorów stanęła na stanowisku, że ratio decidendi Boumediene prowadzi do konkluzji, iż klauzula due process, jak również przynajmniej niektóre inne gwarancje konstytucyjne także obowiązują w Guantánamo ${ }^{142}$. Jednak w 2009 r. w sprawie Kiyebma v. Obama ${ }^{143}$ Sąd Apelacyjny dla Okręgu Dystrykt Kolumbia uznał, że orzeczenie Boumediene ograniczało się do szczególnego kontekstu prawa habeas corpus, a Piąta poprawka jako taka nie ma zastosowania eksterytorialnego w Guantánamo ${ }^{144}$. Identyczne rozstrzygnięcie wydał dwa miesiące później inny panel sądu w sprawie Rasul v. Myers, zauważając, że nawet jeżeli orzeczenie Boumediene podważyło ważność wcześniejszych precedensów Sądu Najwyższego wykluczających zastosowanie klauzuli due process do obcokrajowców poza formalnymi granicami USA ${ }^{145}$, to jedynie sam Sąd Najwyższy jest władny je uchylić1 ${ }^{146}$. Do tego czasu orzeczenia Kiyemba I i Myers II wciąż mają moc obowiązującego precedensu, tak więc osadzonym w Guantánamo nie przysługują gwarancje zawarte w Piątej poprawce ${ }^{147}$.

139 Tamże, s. 746-752. Zob. m.in. Jobson's Case, Latch 160, 82 Eng. Rep. 325 (K.B. 14 Jac. I); Bourn's Case, Cro. Jac. 543, 79 Eng. Rep. 465 (K.B. Mich. 17 Jac. I); King v. Overton, 1 Sid. 387, 82 Eng. Rep. 1173 (K.B. Mich. 20 Car. II). Zob. też King v. The Earl of Crewe ex parte Sekgome, 2 K.B. 576 (C.A.) (1910).

140 Boumediene v. Bush, supra, 553 U.S. at 785-786.

141 S. I. Vladeck, Insular Thinking about Habeas, „Iowa Law Review Bulletin” 2012, Vol. 97, s. 16, 18-19.

142 G. L. Neuman, The Extraterritorial Constitution after Boumediene v. Bush, „Southern California Law Review" 2009, Vol. 82, s. 259, 286; R. Murphy, A. J. Radsan, Due Process and Targeted Killing of Terrorists, „Cardozo Law Review” 2009, Vol. 31, s. 405, 410-411; B. J. Priester, Terrorist Detention: Directions for Reform, „University of Richmond Law Review” 2009, Vol. 43, s. 1021, 1036; Implications of the Supreme Court's Boumediene Decision for Detainees at Guantanamo Bay, Cuba, Hearing Before the House Committee on Armed Services, H.A.S.C. No. 110-166, $110^{\text {th }}$ Cong., $2^{\text {nd }}$ Sess. $(30$ VII 2008), s. 77-78 (Neal K. Katyal).

143 Kiyemba v. Obama, 555 F.3d 1022 (D.C. Cir. 2009) („Kiyemba I”), vacated, 130 S. Ct. 1235 (2010), reinstated as amended, 605 F.3d 1046 (D.C. Cir. 2010) („Kiyemba III”), cert. denied, 131 S. Ct. 1631 (2011).

144 „Kiyemba I”, 555 F.3d at 379-380. Zob. też Kiyemba v. Obama, 561 F.3d 509, fn. 4 (D.C. Cir. 2009) („Kiyemba II”), cert. denied, 130 S.Ct. 1880 (2010).

145 Johnson v. Eisentrager, 339 U.S. 763 (1950).

146 Rasul v. Myers, 563 F.3d 527, 529 (D.C. Cir. 2009), cert. denied, 130 S. Ct. 1013 (2010). W kwestii mocy wiążącej decyzji Sądu Najwyższego w Johnson v. Eisentrager zob. Rodriguez de Quijas v. Shearson/ American Express, Inc., 490 U.S. 477, 484 (1989) (If a precedent of [the Supreme] Court has direct application in a case, yet appears to rest on reasons rejected in some other line of decisions, the Court of Appeals should follow the case which directly controls, leaving to this Court the prerogative of overruling its own decisions).

147 J. A. Geltzer, Of Suspension..., s. 741-742. Zaznaczyć jednak należy, że nawet gdyby sądy uznały, że Piąta poprawka ma zastosowanie w Guantanamo, to pamiętać trzeba, że klauzula due process zezwala 


\section{DETENCJA WOJSKOWA A PRAWO KONFLIKTÓW ZBROJNYCH}

Kolejną grupą norm prawnych, którą należy uwzględnić przy badaniu prawa detencji wojskowej, jest międzynarodowe prawo konfliktów zbrojnych (law of armed conflict, LOAC), znane również jako prawo wojny (law of war). Rozpoczynając od zwyczajowego prawa wojny, należy wpierw podkreślić, że w amerykańskiej doktrynie prawnej istnieje poważny spór co do tego, czy zwyczajowe prawo międzynarodowe jest częścią amerykańskiego porządku prawnego. Wczesne decyzje sądowe uznawały prawo narodów za część prawa federalnego ${ }^{148}$ i potencjalne źródło norm ograniczających kompetencje prezydenta w zakresie prowadzenia wojny ${ }^{149}$. Zwyczajowe prawo międzynarodowe było wówczas zaliczane do tzw. federalnego common law - zbioru norm pozaustawowych stosowanych i rozwijanych przez sądy federalne ${ }^{150}$. Jednak w 1938 r. Sąd Najwyższy w sprawie Erie Railroad v. Tompkins ${ }^{151}$ uznał, że sądy federalne w materiach nieuregulowanych federalnym prawem pozytywnym powinny stosować prawo stanowe ${ }^{152}$. Jedynie kilka szczególnych kategorii federalnego common law przetrwało orzeczenie Erie Railroad i uzyskało aprobatę Sądu Najwyższego ${ }^{153}$. Jest zaś kwestią sporną, czy do grupy tej zalicza się także zwyczajowe prawo międzynarodowe ${ }^{154}$.

Sądownictwo wciąż pozostaje na uboczu sporu o stosowanie zwyczajowego prawa międzynarodowego jako części prawa federalnego, stosując się do reguły sformułowanej przez Sąd Najwyższy w 1900 r. w sprawie The Paquete Habana ${ }^{155}$. Zgodnie z nią prawo narodów jest częścią prawa amerykańskiego, ale zastosowanie przez sąd zwycza-

na pozbawienie wolności wrogich kombatantów, aczkolwiek narzuca pewne wymogi proceduralne, które muszą być przy tym dochowane. Zob. ogólnie Hamdi v. Rumsfeld, 542 U.S. 507 (2004). Law Really State Law?, „Harvard Law Review” 1998, Vol. 111, s. 1824; A. J. Bellia Jr., B. R. Clark, The Federal Common Law of Nations, „Columbia Law Review” 2009, Vol. 109, s. 1; E. A. Young, Sorting Out the Debate over Customary International Law, „Virginia Journal of International Law” 2002, Vol. 42, s. 365; L. Henkin, International Law as Law in the United States, „Michigan Law Review” 1984, Vol. 82, s. 1555, [online] http://dx.doi.org/10.2307/1288495. 
jowego prawa międzynarodowego jest dopuszczalne tylko w razie braku uregulowania traktatowego, wtaściwego aktu ustawowego badź wykonawczego, lub decyzji sadowej ${ }^{156}$. The Paquete Habana zdaje się zatem wykluczać sytuację, w której norma zwyczajowego prawa międzynarodowego exproprio vigore ogranicza kompetencje prezydenta wynikające z innych aktów prawnych ${ }^{157}$.

Nie ulega jednak wątpliwości, że Kongres może posiłkować się zwyczajowym prawem międzynarodowym, odwołując się do niego w ustawach ${ }^{158}$. Stąd też pojawia się pytanie, czy AUMF nie inkorporuje zasad zwyczajowego prawa konfliktów zbrojnych przez implikację $e^{159}$. Zarówno egzekutywa ${ }^{160}$, jak i sądy ${ }^{161}$ zgadzają się, że uprawnienia przyznane prezydentowi przez AUMF można ustalić przez odwołanie do prawa wojny. Stąd teza, że jeżeli uprawnienia egzekutywy przyznane przez AUMF wywodzą się $\mathrm{z}$ prawa wojny, to prawo to definiuje również ich zasięg przedmiotowy ${ }^{162}$.

Sąd Apelacyjny dla Okręgu Dystrykt Kolumbii odniósł się do problemu zastosowania prawa wojny jako ograniczenia kompetencji przyznanych przez AUMF w sprawie Al-Bihani v. Obama ${ }^{163}$. Al-Bihani, obywatel Jemenu, który w Afganistanie należał do paramilitarnej brygady walczącej po stronie talibów, ale nie wykonywał w niej zadań bojowych, argumentował, że według prawa konfliktów zbrojnych nie może podlegać detencji wojskowej ${ }^{164}$. Sąd Apelacyjny, w opinii sędzi Brown, podtrzymał decyzję niższej instancji ${ }^{165}$, uznając, iż LOAC nie zakazuje więzienia al-Bihaniego ${ }^{166}$, a ponadto nie stanowi ograniczenia dla uprawnień prezydenta wynikających z AUMF ${ }^{167}$. Co ciekawe,

156 Tamże, s. 700 ([W]here there is no treaty and no controlling executive or legislative act or judicial decision, resort must be had to the customs and usages of civilized nations).

157 Restatement (Third) of Foreign Relations Law, $\$ 115$, Reporter’s Note 3; Garcia-Mir v. Meese, 788 F.2d 1446 (11 ${ }^{\text {th }}$ Cir. 1986); Brown v. United States, 12 U.S. (8 Cranch) 110, 128 (1814) (C. J. Marshall). Ale zob. A. M. Weisburd, The Executive Branch and International Law, „Vanderbilt Law Review” 1988, Vol. 41, s. 1205.

158 Zob. np. Alien Tort Statute, 28 U.S.C. $\$ 1350 ; 22$ U.S.C. $\$ 462$ (Compelling foreign vessels to depart); 33 U.S.C. $\$ 384$ (Condemnation of piratical vessels); Uniform Code of Military Justice, art. 21, 10 U.S.C. $\$ 821$.

159 Por. R. Goodman, D. Jinks, International Law, U.S. War Powers, and the Global War on Terrorism, „Harvard Law Review” 2005, Vol. 118, s. 2653; J. T. Benson, International Laws-of-War, What are They Good For?, „Creighton Law Review” 2011, Vol. 44, s. 1277.

160 Zob. m.in. Hamlily Brief, s. 1 (The detention authority conferred by the AUMF is necessarily informed by principles of the laws of war) i 3 ([L]aw-of-war principles inform the understanding of what is "necessary and appropriate" [under AUMF]).

${ }_{161}$ Hamdi v. Rumsfeld, 542 U.S. 507, 521 (2004) ([O]ur understanding [of the Congress' grant of authority for the use of „necessary and appropriate force"] is based on longstanding law-of-war principles).

162 C. A. Bradley, J. L. Goldsmith, Congressional Authorization..., s. 2094.

163 Al-Bihani v. Obama, 590 F.3d 866 (D.C. Cir. 2010) („Al Bihani I”).

164 Al-Bihani I, 590 F.3d at 870-71. Zob. szerzej Brief for Petitioner-Appellant, Al-Bihani v. Obama, No. 09-5051, 590 F.3d 866 (D.C. Cir. 2010) (redacted public version).

165 Al-Bihani v. Obama, 594 F.Supp.2d 35 (D.D.C. 2009), aff'd, 590 F.3d 866 (D.C. Cir. 2010).

166 Al-Bihani I, 590 F.3d at 872-874.

167 Tamże, s. 871 (Before considering [the appellant's] arguments in detail, we note that all of them rely 
sama egzekutywa również twierdziła, że uprawnienia wynikające z AUMF trzeba odczytywać przez pryzmat międzynarodowego prawa wojny ${ }^{168}$.

Siedem miesięcy później Sąd odrzucił wniosek o ponowne rozpatrzenie sprawy en banc, wydając przy tej okazji szereg opinii ${ }^{169}$. Sędziowie Sentelle, Ginsburg, Henderson, Rogers, Tatel, Garland, i Griffith wystosowali krótkie oświadczenie stwierdzające, że ich zdaniem dotycząca roli prawa wojny konkluzja panelu rozstrzygającego sprawę stanowi obiter dictum i przez to nie ma mocy precedensu ${ }^{170}$. Z kolei sędzia Williams wydał opinię, w której zgadzał się z decyzją panelu, ale nie z jego rozstrzygnięciem w kwestii znaczenia prawa międzynarodowego ${ }^{171}$. Natomiast wyczerpujące opinie broniące stanowiska, że prawo wojny nie ogranicza uprawnień prezydenta do użycia siły, a więc i stosowania detencji wojskowej, wynikających z AUMF, przedstawili sędziowie Brown i Kavanaugh ${ }^{172}$. Sąd Najwyższy odmówił wydania certiorari, nie komentując w żaden sposób okoliczności sprawy ${ }^{173}$.

Al-Bihani jest w związku z tym nietypowym orzeczeniem i trudno określić, w jakim stopniu ma ono moc precedensu. Jedną z podstawowych reguł stare decisis jest zasada, że sądy dystryktowe oraz panele sądów apelacyjnych są związane rozstrzygnięciami (holdings) zawartymi w publikowanych decyzjach właściwego sądu apelacyjnego, ale nie obiter dictis ${ }^{174}$. Jeżeli zaś decyzja opiera się na dwóch alternatywnych rationibus decidendi, to każde $\mathrm{z}$ nich jest częścią rozstrzygnięcia sądu ${ }^{175}$. Ta reguła przemawiałaby więc za uznaniem, że rozstrzygnięcie o znaczeniu prawa wojny dla interpretacji AUMF w orzeczeniu al-Bihani I ma moc precedensu ${ }^{176}$. Większość czynnych sędziów okręgowych Okręgu Dystrykt Kolumbii była jednak innego zdania ${ }^{177}$. Trudno powiedzieć, czy ich opinia w sprawie al-Bihani II rozstrzyga o charakterze al-Bihani I: z zasady od-

heavily on the premise that the war powers granted by the AUMF and other statutes are limited by the international laws of war. This premise is mistaken).

168 Unclassified Brief for the Appellees, Al-Bihani v. Obama, No. 09-5051, 590 F.3d 866 (D.C. Cir. 2010), s. 23.

169 Al-Bihani v. Obama, 619 F.3d 1 (D.C. Cir. 2010).

170 Tamże, s. 1 (Sentelle, C.J., et al., concurring) (We decline to en banc this case to determine the role of international law-of-war principles in interpreting the AUMF because [...] the panel's discussion of that question is not necessary to the disposition of the merits).

171 Tamże, s. 53 (Williams, J., concurring).

172 Tamże, s. 2 (Brown, J., concurring); s. 9 (Kavanaugh, J., concurring).

173131 S. Ct. 1814 (2011).

174 Gersman v. Group Health Ass'n, Inc., 975 F.2d 886, 897 (D.C. Cir. 1992); L. B. Solum, Stare Decisis, Law of the Case, and Judicial Estoppel, [w:] Moore's Federal Practice, red. D. R. Coquillette [i in.], t. 18, New York 2007, $\$ 134.02[2]$ i 134.03; T. E. Baker, A Primer on the Jurisdiction of the U.S. Courts of Appeals, Washington 2009, s. 6 .

175 Woods v. Interstate Realty Co., 337 U.S. 535, 537 (1949); McLellan v. Mississippi Power \& Light Co., 545 F.2d 919, 925 fn. 21 ( $5^{\text {th }}$ Cir. 1977) (en banc); Russell v. Commissioner, 678 F.2d 782, 785 fn. 2 ( $9^{\text {th }}$ Cir. 1982); Bravo v. United States, 532 F.3d 1154, 1162-1163 (11 $1^{\text {th }}$ Cir. 2008).

176 Al-Bihani v. Obama, 619 F.3d 1, 2-3 (D.C. Cir. 2010) („Al Bihani II”) (Brown, J., concurring).

177 Tamże, s. 1 (Sentelle, C.J., et al., concurring). 
mowa ponownego rozpatrzenia sprawy ${ }^{178}$ nie ustanawia precedensu, tak więc jedynie formalna, publikowana opinia sądu en banc mogłaby uchylić orzeczenie al-Bihani $I^{179}$. Jednak żaden sąd dystryktowy nie oparł się na omawianym rozstrzygnięciu, prawdopodobnie zdając sobie sprawę z tego, że argumenty nie zostałyby przyjęte przez większość sędziów sądu en banc. Część badaczy utrzymuje też, że częściowa kodyfikacja prawa detencji wojskowej w NDAA, która mówi o detencji w oparciu o prawo wojny (under the laws of war), ustawowo uchyla al-Bihani I, dopuszczając stosowanie prawa wojny $\mathrm{w}$ interpretacji AUMF ${ }^{180}$.

Prawo konfliktów zbrojnych to nie tylko prawo zwyczajowe - obejmuje ono również umowy i konwencje międzynarodowe kodyfikujące tradycyjne normy prawa wojny, wśród których najistotniejszą rolę odgrywają konwencje haskie z 1899 i 1907 r. oraz konwencje genewskie z 1949 r. (wraz z protokołami dodatkowymi) ${ }^{181}$. Wśród nich do omawianego problemu odnosi się przede wszystkim konwencja trzecia, dotycząca traktowania jeńców wojennych ${ }^{182}$. Zostały ona ratyfikowana przez Stany Zjednoczone w 1955 r. ${ }^{183}$

Wstępnym problemem, który trzeba rozstrzygnąć, jest określenie, czy konwencja genewska jest bezpośrednio stosowalna (self-executing) jako część amerykańskiego porządku prawnego ${ }^{184}$. Jakkolwiek konstytucyjna klauzula supremacji wymienia traktaty zawarte w imieniu Stanów Zjednoczonych jako jedno ze źródeł prawa federalnego ${ }^{185}$, to już od XIX w. ${ }^{186}$ orzecznictwo uznaje, że taki charakter mają jedynie tzw. traktaty bezpośrednio stosowalne, tj. takie, których przepisy tworzą nie tylko zobowiązania

178 Por. Hopfmann v. Connolly, 471 U.S. 459, 461 (1985) (per curiam); Brown v. Allen, 344 U.S. 443, 543 (1953) (Jackson, J., dissenting); Luckey v. Miller, 929 F.2d 618, 621-622 (11 ${ }^{\text {th }}$ Cir. 1991); R. L. Stern, E. Gressman, Supreme Court Practice, Washington 2002, s. 334-339 (w odniesieniu do odmowy przyznania certiorari); Federal Procedure. Lawyers Edition, St. Paul 1981-2013, §3:933.

179 „Al-Bihani II”, 619 F.3d at 3 (Brown, J., concurring).

180 S. I. Vladeck, M. S. Lederman, The NDAA: The Good, the Bad, and the Laws of War - Part II, Lawfare, 31 XII 2011, [online] http://www.lawfareblog.com/2011/12/the-ndaa-the-good-the-bad-and-the-laws-of-war-part-ii/, 13 V 2013. Ale wbrew temu zob. Brief of Amici Curiae Senators John McCain, Lindsey Graham, and Kelly Ayotte in Support of Appellants, Hedges v. Obama, Nos. 12-3176, 12 -3644, 2012 WL 3999839 (2 ${ }^{\text {nd }}$ Cir. 2012), 13 XI 2012, s. 18-19.

181 W 1977 r. przyjęto dwa protokoły dodatkowe do konwencji genewskich, ale Stany Zjednoczone dotychczas (na dzień 23 VII 2013 r.) nie ratyfikowały żadnego z nich.

182 Geneva Convention (III) Relative to the Treatment of Prisoners of War, Aug. 12, 1949, 6 U.S.T. 3316, T.I.A.S. No. 3364 (1949).

183101 Congressional Record 9958 -9973 (July 6, 1955). Instrumenty ratyfikacyjne zostały złożone 14 VII 1955 r. Zob. 6 U.S.T. 3316 i 6 U.S.T. 3516.

184 Zob. ogólnie V. P. Nanda, D. K. Pansius, Litigation of International Disputes in U.S. Courts, Eagan 2005 (suplement 2013), \$10:23; B. M. Carnahan, In re Medina: Are the 1949 Geneva Conventions Self-Executing?, „Air Force Law Review” 1987, Vol. 26, s. 123; D. Jinks, D. Sloss, Is the President Bound by the Geneva Conventions?, „Cornell Law Review” 2004, Vol. 90, s. 97, 121-129.

185 U.S. Const., art. VI cl. 2.

186 Zob. Foster v. Neilson, 27 U.S. (2 Pet.) 253, 314-315, 7 L.Ed. 415 (1829); Whitney v. Robertson, 124 U.S. 190, 194 (1888). 
międzynarodowe, ale też prawa i zobowiązania jednostkowe ${ }^{187}$. To, czy dany traktat jest bezpośrednio stosowalny, zależy od charakteru jego postanowień i intencji władz politycznych uczestniczących w procesie ratyfikacji (prezydenta i Senatu) ${ }^{188}$.

W przypisie do opinii większości w sprawie Johnson v. Eisentrager Sąd Najwyższy zasugerował, że konwencja genewska o jeńcach wojennych z 1929 r. nie może być bezpośrednio stosowana przez sądy ${ }^{189}$. Sąd Najwyższy nie odniósł się dotychczas wprost do bezpośredniej stosowalności konwencji z 1949 r. ${ }^{190}$, ale bogate w tej kwestii jest orzecznictwo sądów dystryktowych i apelacyjnych ${ }^{191}$, które skłania się ku tezie, że konwencje genewskie nie są bezpośrednio stosowalne ${ }^{192}$. Takie stanowisko zajęły wszystkie sądy apelacyjne, które rozpatrywały omawiany problem ${ }^{193}$, jak również większość sądów dystryktowych ${ }^{194}$ (aczkolwiek dwa z nich doszły do odmiennych wniosków ${ }^{195}$ ) i Trybunał Apelacyjny ds. Imigracyjnych ${ }^{196}$. Jednak w 2006 r. w sprawie Hamdan v. Rumsfeld Sąd Najwyższy uznał, iż jest władny rozpatrzyć skargi na jurysdykcję trybunałów wojskowych powołujące się na trzecią konwencję ${ }^{197}$. W odpowiedzi na to Kongres, chcąc ograniczyć sądową kontrolę legalności stosowania detencji wojskowej, w ustawie z 2006 r. zastrzegł, iż konwencja genewska nie może być stosowana przez sądy w sprawach o ha-

187 Medellin v. Texas, 552 U.S. 491, 504-506 (2008).

188 Restatement (Third) of Foreign Relations Law, $\$ 111(4)(\mathrm{a})$; C. M. Vazquez, The Four Doctrines of Self-Executing Treaties, „American Journal of International Law” 1995, Vol. 89, s. 695, 700-710, [online] http://dx.doi.org/10.2307/. Wbrew temu zob. D. Jinks, D. Sloss, Is the President..., s. 124. Ale zob. Medellin v. Texas, 552 U.S. at 505 (cyt. Igartua-De La Rosa v. United States, 417 F.3d 145, 150 ( ${ }^{\text {st }}$ Cir. 2005) (en banc) (J. C. Boudin)).

189 Johnson v. Eisentrager, 339 U.S. 763, 789 fn. 14 (1950). Zob. też Holmes v. Laird, 459 F.2d 1211, 1222 (D.C. Cir. 1972); Hamdan v. Rumsfeld, 415 F.3d 33, 39 (D.C. Cir. 2005) („Hamdan I”), rev'd and remanded, 548 U.S. 557 (2006); Al-Bihani v. Obama, 619 F.3d 1, 21-22 (D.C. Cir. 2010). Ale zob. Brief for Louis Henkin et al. as Amici Curiae, Hamdan v. Rumsfeld, No. 05-184, 548 U.S. 557 (U.S. 2006).

190 V. P. Nanda, D. K. Pansius, Litigation..., $\$ 10: 23$ fn. 66 i tekst.

191 Zob. D. Jinks, D. Sloss, Is the President..., s. 127-128 fns. 149-151.

192 Federal Procedure. Lawyers Edition, \$36:509 (suplement 2013).

193 Huynh Thi Anh v. Levi, 586 F.2d 625, 629 (6 ${ }^{\text {th }}$ Cir. 1978); Tel-Oren v. Libyan Arab Republic, 726 F.2d 774, 808-809 (D.C. Cir. 1984) (Bork, J., concurring); Hamdi v. Rumsfeld, 316 F.3d 450, 468, 185 A.L.R. Fed. 751 ( $4^{\text {th }}$ Cir. 2003); Al Odah v. United States, 321 F.3d 1134, 1147 (D.C. Cir. 2003), rev'd sub nom. Rasul v. Bush, 542 U.S. 466 (2004) (on other grounds).

194 Zob. m.in. Handel v. Artukovic, 601 F.Supp. 1421, 1424-1426 (C.D. Cal. 1985); American Baptist Churches in the U.S.A. v. Meese, 712 F.Supp. 756, 770 (N.D. Cal. 1989); Linder v. Calero Portocarrero, 747 F.Supp. 1452, 1462-1463 (S.D. Fla. 1990); United States v. Fort, 921 F.Supp. 523, 526 (N.D. Ill. 1996); Iwanowa v. Ford Motor Co., 67 F.Supp.2d 424, 439 fn. 16 (D.N.J. 1999).

195 United States v. Lindh, 212 F.Supp.2d 541, 553 (E.D.Va. 2002); United States v. Noriega, 808 F.Supp. 791 (S.D. Fla. 1992), aff'd, 117 F.3d 1206 (11 ${ }^{\text {th }}$ Cir. 1997) (dictum).

196 In re Medina, 19 I. \& N. Dec. 734, 740-741, Interim Decision 3078 (B.I.A. 1988).

197 Hamdan v. Rumsfeld, 548 U.S. 557, 628 (2006). Sąd nie rozstrzygnął jednak, czy stosuje on ją jako traktat bezpośrednio włączony do prawa wewnętrznego, czy tylko jako element prawa wojny, do którego odwoływała się właściwa ustawa. Tamże, s. 627-628 oraz fn. 58; V. P. Nanda, D. K. Pansius, Litigation..., \$10:23. 
beas $\operatorname{corpus}^{198}$. W 2009 r. przepis ten uległ zmianie i obecnie stanowi, że konwencja nie może być interpretowana przez sądy jako podstawa prawna roszczeń indywidualnych wysuwanych przez wrogich kombatantów ${ }^{199}$.

Odrębną kwestią jest to, w jakim zakresie postanowienia materialne konwencji mają zastosowanie do konfliktów z Al-Kaidą i talibami. Co do zasady konwencja obowiązuje jedynie w konfliktach międzypaństwowych ${ }^{200}$. Wyjątkiem jest art. 3, formułujący minimalne normy humanitarnego prowadzenia konfliktów niemiędzynarodowych rozgrywających się na terytorium jednej ze stron ${ }^{201}$. Jego zastosowanie do „wojny z terroryzmem” też było przedmiotem sporu ${ }^{202}$ : opinia OLC z 2002 r. uznawała, iż art. 3 ma zastosowanie tylko wobec wojen domowych na terytorium walczącego państwa, a nie do konfliktów transnarodowych ${ }^{203}$. Stanowisko to zostało jednak odrzucone przez Sąd Najwyższy w 2006 r. w sprawie Hamdan v. Rumsfeld ${ }^{204}$. Sąd uznał, iż każdy konflikt zbrojny niebędący konfliktem międzypaństwowym w rozumieniu konwencji jest konfliktem o charakterze niemiędzynarodowym, do którego zastosowanie ma art. 3.

W przypadku konfliktu z talibami sytuacja jest bardziej złożona, gdyż jakkolwiek przed 2001 r. sprawowali oni kontrolę nad większością terytorium Afganistanu, to jedynie trzy państwa uznały ich za legalny rząd tego $\mathrm{kraju}^{205}$. W tej sytuacji powstało pytanie, czy konflikt z talibami jesienią 2001 r. był konfliktem przeciwko Afganistanowi, państwu-stronie konwencji, czy też interwencją USA w wojnę domową między tali-

198 Military Commissions Act of 2006, $₫ 5(\mathrm{~b})$. Zob. szerzej M. P. Fischer, Applicability of the Geneva Conventions to "Armed Conflict” in the War on Terror, „Fordham International Law Journal” 2007, Vol. 30, s. 509, 522-523.

199 U.S.C. $\$ 948 \mathrm{~b}(\mathrm{e})$, wprowadzona przez Military Commissions Act of 2009, Pub. L. No. 111-84, Div. A, Title XVIII, 123 Stat. 2190, 2574 (2009).

200 Geneva Convention (III)..., art. 2. Zob. szerzej J. de Preux, F. Siordet, Geneva Convention Relative to the Treatment of Prisoners of War. Commentary, przel. A. P. de Heney, Geneva 1960, s. 19-27, The Geneva Conventions of 12 August 1949, red. J. S. Pictet, t. 3.

201 Geneva Convention (III)..., art. 3. Art. 3 zakazuje m.in. przemocy wobec osób nieuczestniczących w działaniach zbrojnych lub pozostających hors de combat, naruszania ich godności osobistej, brania zakładników czy wykonywania egzekucji bez wyroku sądowego. Zob. szerzej J. de Preux, F. Siordet, Geneva Convention..., s. 27-44.

202 Zob. M. P. Fischer, Applicability of the Geneva Conventions..., s. 517; B. E. Shumate, New Rules for a New War: The Applicability of the Geneva Conventions to al Qaeda and Taliban Detainees Captured in Afghanistan, „New York International Law Review” 2005, Vol. 18, s. 1, 31-32; S. D. Murphy, Decision Not to Regard Persons Detained in Afghanistan as POWs, "American Journal of International Law” 2002, Vol. 96, s. 475, [online] http://dx.doi.org/10.2307/2693945.

203 J. S. Bybee, Re: Application of Treaties and Laws to al Qaeda and Taliban Detainees, Memorandum for A. R. Gonzales, Counsel to the President, and W. J. Haynes II, General Counsel of the Department of Defense (O.L.C. 22 I 2002), s. 5-9.

204 Hamdan v. Rumsfeld, 548 U.S. 557, 630-631 (2006).

205 Były to: Pakistan, Arabia Saudyjska oraz Zjednoczone Emiraty Arabskie.Zob. W.H. Parks, Combatants, [w:] The War in Afghanistan. A Legal Analysis, red. M. N. Schmitt, Newport 2009, s. 247, 255-256, International Law Studies, 85. 
bami a zwalczającymi ich siłami skupionymi w tzw. Sojuszu Północnym ${ }^{206}$. Problem ten był na początku 2002 r. przedmiotem poważnej dyskusji wewnątrz egzekutywy ${ }^{207}$. Ostatecznie jednak prezydent Bush uznał w memorandum z 7 lutego 2002 r., że konwencja ma zastosowanie do walk $\mathrm{z}$ talibami ${ }^{208}$, ale pojmanym talibom nie przysługuje status jeńców wojennych, gdyż nie spełniają oni warunków określonych w art. 4 dla wojsk nieregularnych ${ }^{209}$ : posiadania dowódcy odpowiedzialnego za działania podwładnych, używania stałego i widocznego z daleka oznaczenia, otwartego noszenia broni oraz przestrzegania praw i zwyczajów wojny ${ }^{210}$.

Poza zakresem tego artykułu pozostaje określenie, czy zawarte w memorandum prezydenckim ustalenia faktyczne są poprawne ${ }^{211}$. Pozostaje jednak problem, czy decyzja prezydenta jest zgodna z art. 5 konwencji, stanowiącym, iż w razie wątpliwości, czy więźniowi przysługuje status jeńca wojennego, winien on być tak traktowany do czasu rozstrzygnięcia tej kwestii przez właściwy trybuna ${ }^{212}$. W razie wątpliwości indywidualnych, np. co do przynależności osób pojmanych do danej organizacji, przepis ten bezspornie wymaga orzeczeń jednostkowych ${ }^{213}$. Jednak sądy prawdopodobnie uznałyby, że prezydent i Departament Obrony, jako organy odpowiedzialne za stosowanie konwencji, mają w prawie USA szczególne prawo do jej interpretacji na podstawie tzw. doktryny Chevron, przyjęłyby więc ich wykładnię ${ }^{214}$. Ponadto rozstrzygnięcie o statusie całej organizacji z punktu widzenia art. 4 wiąże się z ustaleniami dotyczącymi raczej legisla-

206 Taką interpretację przyjął m.in. największy koalicjant USA podczas operacji afgańskiej, Zjednoczone Królestwo. D. Turns, The Treatment of Detainees and the "Global War on Terror": Selected Legal Issues, [w:] International Law and Military Operations, red. M. D. Carsten, Newport 2008, s. 199, 214, International Law Studies, 84.

C. Garraway, Afghanistan and the Nature of Conflict, [w:] The War in Afghanistan..., s. 157, 167-176.

Memorandum from President George W. Bush to the Vice President et al., Humane Treatment of Taliban and al Qaeda Detainees (7 II 2002), \$2(b) i (d). Zob. też Memorandum from the Secretary of Defense to Chairman of the Joint Chiefs of Staff, Legal Status of Taliban and al Qaeda (19 I 2002).

209 Zob. ogólnie M. Marcinko, „Status terrorysty” w świetle międzynarodowego prawa humanitarnego, [w:] Walka z terroryzmem wświetle prawa międzynarodowego, red. K. Lankosz, M. Chorośnicki, P. Czubik, Bielsko-Biała 2005, s. 117, 126-127.

210 Geneva Convention (III)..., art. 4(2); J. de Preux, F. Siordet, Geneva Convention..., s. 59-61.

211 Zaznaczyć jednak trzeba, że w 2002 r. zaakceptował je Sąd Dystryktowy dla Wschodniego Dystryktu Wirginii. United States v. Lindh, 212 F.Supp.2d 541, 556-558 (E.D.Va. 2002).

212 Geneva Convention (III)..., art. 5. W USA artykuł ten implementuje regulacja wojskowa 190-8 (Enemy Prisoners of War, Retained Personnel, Civilian Internees and Other Detainees, Army Regulation 190-8, OPNAVINST 3461.6, AFJI 31-304, MCO 3461.1 (1997), § 1-6).

213 Komentarz do konwencji podaje dwa przykłady osób o wątpliwym statusie w rozumieniu art. 5: dezerterzy i wojskowi, którzy utracili dokumenty tożsamości. J. de Preux, F. Siordet, Geneva Convention..., s. 77.

214 Zob. Chevron U.S.A. Inc. v. Natural Resources Defense Council, Inc., 467 U.S. 837 (1984). W kwestii zastosowania tej doktryny do stosunków zagranicznych zob. m.in. C. A. Bradley, Chevron Deference and Foreign Affairs, „Virginia Law Review” 2000, Vol. 86, s. 649, [online] http://dx.doi. org/10.2307/1073844; E. A. Posner, C. R. Sunstein, Chevronizing Foreign Relations Law, „Yale Law Journal" 2007, Vol. 116, s. 1170. David J. Barron i Elena Kagan przekonują, że cele doktryny Chevron są realizowane zwłaszcza wówczas, gdy decyzję interpretacyjną podejmuje politycznie odpowiedzial- 
tive facts niż adjudicative facts (by użyć terminologii z prawa administracyjnego ${ }^{215}$ ), do czego trybunały przewidziane regulacją wojskową 190-8 nie są przystosowane $e^{216}$.

\section{DETENCJA WOJSKOWA A MIĘDZYNARODOWE NORMY OCHRONY PRAW CZEOWIEKA}

Kolejną grupą norm międzynarodowych, których zastosowanie do detencji wojskowej należy przeanalizować, jest międzynarodowe prawo ochrony praw człowieka (international human rights law, IHRL). Zarówno zwyczajowe $\mathrm{e}^{217}$, jak i traktatowe ${ }^{218}$ normy IHRL zakazują długoterminowego arbitralnego pozbawienia wolności. Nie ma jednak potrzeby rozpatrywać w tym artykule, czy detencja wojskowa w formie stosowanej obecnie przez Stany Zjednoczone jest zgodna z tym zakazem, gdyż (przynajmniej z perspektywy amerykańskiego prawa wewnętrznego) IHRL nie ma zastosowania do omawianej sytuacji ${ }^{219}$.

Stany Zjednoczone konsekwentnie stoją na stanowisku, że ani globalny konflikt przeciwko Al-Kaidzie, ani też konflikt w Afganistanie nie podlegają normom IHRL $\mathrm{z}$ dwóch przyczyn ${ }^{220}$. Po pierwsze, działania te podlegają prawu konfliktów zbrojnych, które jako lex specialis deroguje IHRL, będące lex generalis ${ }^{221}$. Po drugie, USA uznają, iż IHRL nie ma zastosowania eksterytorialnego, zauważając, że zobowiązania traktatowe w tym zakresie mówią o prawach osób obecnych na terytorium danego państwa 222 .

ny urzędnik wysokiego stopnia. D. J. Barron, E. Kagan, Cheuron's Nondelegation Doctrine, „Supreme Court Review” 2001, Vol. 2001, s. 201.

215 Rozróżnienie to omawiają m.in. K. C. Davis, An Approach to Problems of Evidence in the Administrative Process, „Harvard Law Review” 1942, Vol. 55, s. 364, 402, [online] http://dx.doi.org/10.2307/1335092; Ch. H. Koch, Administrative Law and Practice, Eagan 2010, § 1:20 [7]; Federal Rules of Evidence, Rule 201, 1975 Advisory Committee Note.

216 Zob. M. P. Fischer, Applicability of the Geneva Conventions..., s. 528-529.

217 Restatement (Third) of Foreign Relations Law, $₫ 702$; Sosa v. Alvarez-Machain, 542 U.S. 692, 737 (2004).

218 International Covenant on Civil and Political Rights, Dec. 16, 1966, S. Treaty Doc. No. 95-20, 6 I.L.M. 368, 999 U.N.T.S. 171 (1967), art. 7.

219 Khalid v. Bush, 355 F.Supp.2d 311 (D.D.C. 2005), vacated and dismissed on other grounds, 476 F.3d 981 (D.C. Cir. 2007), rev'd and remanded on other grounds, 553 U.S. 723 (2008).

220 R. M. Chesney, Who May be Held?..., s. 786-788.

221 U.S. Department of State, United States Responses to Selected Recommendations of the Human Rights Committee (2007), s. 4; Operational Law Handbook, red. S. Condron, Charlottesville 2011, s. 44.

222 U.S. Department of State, U.S. Responses..., s. 1-2; Summary Record of the 1405th Meeting: United States of America, UN ESCOR Hum. Rts. Comm., 53 $3^{\text {rd }}$ Sess., 1504 ${ }^{\text {th }}$ Mtg., U.N. Doc. CCPR/C/ SR 1405 (1995), \$7, 20. Zob. szerzej J. B. Bellinger III, V. M. Padmanabhan, Detention Operations in Contemporary Conflicts: Four Challenges for the Geneva Conventions and Other Existing Law, „American Journal of International Law” 2011, Vol. 105, s. 201, 211, [online] http://dx.doi. org/10.5305/amerjintelaw.105.2.0201. 
Jednak nawet w razie odrzucenia interpretacji IHRL przyjmowanej konsekwentnie przez Stany Zjednoczone właściwe normy tego prawa i tak nie mają w USA statusu prawa wewnętrznego ${ }^{223}$. Większość dokumentów, na które powołują się badacze i prawnicy kwestionujący legalność detencji wojskowej w oparciu o IHRL, albo nie została nigdy przyjęta przez Stany Zjednoczone, albo też (jak np. Powszechna deklaracja praw cztowieka) została przez sądy USA uznana za pozbawione jakiegokolwiek charakteru wiążącego ${ }^{224}$. Jedynym traktatem IHRL, który potencjalnie mógłby mieć zastosowanie w kwestii military detention, a został ratyfikowany przez Stany Zjednoczone, jest Międzynarodowy pakt praw obywatelskich i politycznych (The International Covenant on Civil and Political Rights, ICCPR) ${ }^{225}$. Jednak traktat ten, jak wyraźnie stanowi senacka rezolucja wyrażająca zgodę na ratyfikację, nie jest bezpośrednio stosowalny w Stanach Zjednoczonych i nie stanowi części ich wewnętrznego porządku prawnego ${ }^{226}$.

\section{PODSUMOWANIE}

Przedstawiona powyżej analiza jest istotnym punktem wyjścia dla dalszych rozważań nad treścią materialnego i proceduralnego prawa detencji wojskowej, gdyż wynikają $\mathrm{z}$ niej pewne zasadnicze konkluzje determinujące w znacznym stopniu te rozważania. Po pierwsze, pozwala wskazać podstawy prawne detencji wojskowej w postaci rezolucji autoryzującej użycie siły (AUMF) z $2001 \mathrm{r}^{227} \mathrm{i}$ ustawy autoryzacyjnej Departamentu Obrony (NDAA) na rok 2012 228. Warto zauważyć, że jakkolwiek w pierwszych latach po 2001 r. samo istnienie tej podstawy prawnej budziło poważne kontrowersje, to po orzeczeniu Hamdi v. Rumsfeld sprawa została uznana przez sądy za jednoznacznie rozstrzygniętą i po 2004 r. argument, że detencja wojskowa per se nie ma oparcia ustawowego, nie był już podnoszony, tak więc ten wątek właściwie nie pojawia się w bieżącym orzecznictwie.

223 Zob. ogólnie S. N. Katz, A New American Dilemma? U.S. Constitutionalism vs. International Human Rights, „University of Miami Law Review” 2003, Vol. 58, s. 323, 331-337.

224 Sosa v. Alvarez-Machain, 542 U.S. 692, 734-735 (2004) ([T]he Declaration does not of its own force impose obligations as a matter of international law); Haitian Refugee Ctr. v. Gracey, 809 F.2d 794, 816 fn. 17 (D.C. Cir. 1987); Igartua-De La Rosa v. United States, 417 F.3d 145, 150 ( $1^{\text {st }}$ Cir. 2005); Flores v. Southern Peru Copper Corp., 414 F.3d 233, 259 ( $2^{\text {nd }}$ Cir. 2003); Jogi v. Voges, 425 F.3d 367, 373 ( $7^{\text {th }}$ Cir. 2005).

225 International Covenant on Civil and Political Rights, Dec. 16, 1966, S. Treaty Doc. No. 95-20, 6 I.L.M. 368, 999 U.N.T.S. 171 (1967).

226 U.S. reservations, declarations, and understandings, International Covenant on Civil and Political Rights, Declaration No. 1, 138 Congressional Record S4781, S4784 (daily ed., Apr. 2, 1992) (The United States declares that the provisions of Articles 1 through 27 of the Covenant are not self-executing). Zob. też Dutton v. Warden, FCI Estill, 37 Fed.Appx. 51, 52-53 (4 $4^{\text {th }}$ Cir. 2002) (argument powołujący się na ICCPR w sprawie o habeas corpus jest „oczywiście bezzasadny”).

227 Authorization for Use of Military Force, Sept. 18, 2001, Pub. L. No. 107-40, 115 Stat. 224 (2001).

228 National Defense Authorization Act for FY 2012, Pub. L. No. 112-81, §1021(a), 125 Stat. 1298, 1562 (2011). 
Ze względu na ogólny charakter sformułowań AUMF konieczne jest jednak poszukiwanie innych, bardziej szczegółowych źródeł prawa detencji wojskowej. W tej kwestii sytuacja jest bardziej złożona. Orzecznictwo Sądu Apelacyjnego dla Okręgu Dystrykt Kolumbii jednoznacznie uznaje, że do większości zatrzymanych nie mają zastosowania konstytucyjne gwarancje praw i wolności indywidualnych, z wyjątkiem przywileju habeas corpus ${ }^{229}$. Obecnie wniosek ten musi być uznawany za "prawo okręgu” (law of the circuit), ale nie jest wcale przesądzone, że stanowisko takie podzieliłby Sąd Najwyższy, gdyby sędziowie zdecydowali się ponownie włączyć się w kształtowanie prawa detencji. Jeszcze bardziej niejasna jest sytuacja w kwestii zwyczajowego prawa międzynarodowego: jego zastosowanie formalnie wyklucza decyzja Okręgu Dystrykt Kolumbii w sprawie al-Bihani, ale istnieją poważne wątpliwości zarówno co do jej mocy precedensowej, jak i szans na ewentualne podtrzymanie jej konkluzji przez sąd en banc. Analiza kolejnych orzeczeń również wskazuje na posiłkowanie się zwyczajowym prawem konfliktów zbrojnych przez Sąd Apelacyjny w sytuacjach niejasnych ${ }^{230}$, ale jego wpływ na orzecznictwo jest ograniczony. Jeszcze rzadziej sądy odwołują się do konwencji genewskich, co pokazuje, że głośny spór w doktrynie o ich zastosowanie do osadzonych w Guantánamo nie ma przełożenia na orzecznictwo.

Jeżeli zatem nie normy konstytucyjne i międzynarodowe, to co (poza ogólnie napisaną rezolucją autoryzacyjną z $2001 \mathrm{r}$. i niedawną ustawą NDAA) jest źródłem prawa detencji wojskowej? Komentatorzy zauważają, że prawo to ma w dużym stopniu charakter prawa sędziowskiego (judge-made law), kreowanego w typowym dla common law procesie inkrementalnego tworzenia nowych norm na drodze precedensowych decyzji sądowych ${ }^{231}$. Punktem wyjścia dla niego jest prawo wewnętrzne ${ }^{232}$, tj. przede wszystkim AUMF, późniejsze ustawy (zwłaszcza ustawy o trybunałach wojskowych z $2006 \mathrm{r}$. i 2009 r. ${ }^{233}$ ) oraz orzecznictwo dotyczące stosowania detencji wojskowej we wcześniejszych konfliktach, przede wszystkim sprawy Exparte Milligan 234 i Ex parte Quirin ${ }^{235}$. Analiza norm wypracowanych na drodze omawianego procesu jest już jednak tematem na odrębny artykuł.

229 Kiyemba v. Obama, 555 F.3d 1022 (D.C. Cir. 2009); Rasul v. Myers, 563 F.3d 527 (D.C. Cir. 2009).

230 Zob. m.in. Warafi v. Obama, 409 Fed.Appx. 360 (D.C. Cir. 2011).

231 Zob. ogólnie B. Wittes, R. M. Chesney, L. Reynolds, The Emerging Law of Detention 2.0...

232 Al-Bihani v. Obama, 590 F.3d 866, 871-872 (D.C. Cir. 2010) (The sources we look to for resolution of [the cases] are the sources courts always look to: the text of relevant statutes and controlling domestic caselaw).

233 Military Commissions Act of 2006, Pub. L. No. 109-366, 120 Stat. 2600 (2006); Military Commissions Act of 2009, Pub. L. No. 111-84, Div. A, Title XVIII, 123 Stat. 2190, 2574 (2009).

234 Exparte Milligan, 71 U.S. (4 Wall.) 2 (1866).

235 Exparte Quirin, 317 U.S. 1 (1942). 


\section{BIBLIOGRAFIA}

\section{PODMIOTOWA}

\section{Akty prawne}

28 U.S.C., ch. 153: Habeas Corpus, $\$ \$ 2241$ et seq. (1947 z późn. zm.).

Agreement between the United States and Cuba for the Lease of Lands for Coaling and Naval

Stations, Feb. 23, 1903, Treaty Series No. 418 (1903).

An Act for the Punishment of Certain Crimes against the United States, Apr. 30, 1790, $1^{\text {st }}$ Cong.,

$2^{\text {nd }}$ Sess., ch. 9, 1 Stat. 112 (1790).

An Act for the Safe Keeping and Accommodation of Prisoners of War, July 6, 1812, $12^{\text {th }}$ Cong., $1^{\text {st }}$

Sess., ch. 128, 2 Stat. 777 (1812).

Antiterrorism and Effective Death Penalty Act of 1996, Pub. L. No. 104-132, 110 Stat. 1214

(1996).

Authorization for Use of Military Force, Sept. 18, 2001, Pub. L. No. 107-40, 115 Stat. 224

(2001)

Constitution of the United States, Sep. 17, 1788 (za: United States Code, 2006 ed.).

Detainee Treatment Act of 2005 (Department of Defense Appropriations Act for FY 2006), Pub. L.

No. 109-148, Div. A, Title X, 119 Stat. 2680, 2739-44 (2005).

Geneva Convention (III) Relative to the Treatment of Prisoners of War, Aug. 12, 1949, 6 U.S.T.

3316, T.I.A.S. No. 3364 (1949).

Geneva Convention Relative to the Treatment of Prisoners of War, July 27, 1929, 47 Stat. 2021

(1929).

Hague Convention (IV): Respecting the Laws and Customs of War on Land, Oct. 18, 1907, 36

Stat. 2277 (1907).

International Covenant on Civil and Political Rights, Dec. 16, 1966, S. Treaty Doc. No. 95-20,

6 I.L.M. 368, 999 U.N.T.S. 171 (1967).

Lease to the United States by the Government of Cuba of Certain Areas of Land and Water for

Naval or Coaling Stations in Guantanamo and Babia Honda, July 2, 1903, Treaty Series

No. 426 (1903).

Magna Carta, 9 Hen. III (1225).

Military Commissions Act of 2006, Pub. L. No. 109-366, 120 Stat. 2600 (2006).

Military Commissions Act of 2009, Pub. L. No. 111-84, Div. A, Title XVIII, 123 Stat. 2190, 2574 (2009) (10 U.S.C., ch. 47a).

National Defense Authorization Act for FY 2012, Pub. L. No. 112-81, 125 Stat. 1298 (2011) (10 U.S.C., $\$ 801$ note).

Statute of Treasons of 1351 (A Declaration which Offences shall be adjudged Treason), 25 Edw. III st. 5 ch. 2 (1351).

Treaty Defining Relations with Cuba, May 29, 1934, 48 Stat. 1683, Treaty Series No. 866 (1934).

War Powers Resolution, Pub. L. No. 93-148, 87 Stat. 555 (1973) (50 U.S.C. \$\$ 1541 et seq.). 


\section{Projekty aktów prawnych}

Detainee Security Act of 2011, H.R. 968, 112 ${ }^{\text {th }}$ Cong. (2011).

Enemy Belligerent Interrogation, Detention, and Prosecution Act, S. 3081, $111^{\text {th }}$ Cong. (2010).

Enemy Combatant Detention Review Act of 2008, S. 3401, $110^{\text {th }}$ Cong. (2008).

Military Detainee Procedures Improvement Act of 2011, S. 551, 112 ${ }^{\text {th }}$ Cong. (2011).

Terrorist Detention Review Reform Act, S. 3707, $111^{\text {th }}$ Cong. (2010).

\section{Akty wykonawcze}

Enemy Prisoners of War, Retained Personnel, Civilian Internees and Other Detainees, Army Regulation 190-8, OPNAVINST 3461.6, AFJI 31-304, MCO 3461.1 (1997).

Memorandum from President George W. Bush to the Vice President et al., Humane Treatment of Taliban and al Qaeda Detainees (7 II 2002).

Memorandum from the Secretary of Defense to Chairman of the Joint Chiefs of Staff, Legal Status of Taliban and al Qaeda (19 I 2002).

Notice, Detention, Treatment, and Trial of Certain Non-Citizens in the War against Terrorism, Presidential Military Order, 66 F.R. 57,833 (13 XI 2001).

Decyzje sądowe i administracyjne

32 County Sovereignty Comm.v. Dep’t of State, 292 F.3d 797 (D.C. Cir. 2002).

Al Maqaleh v. Gates, 605 F.3d 84 (D.C. Cir. 2010).

Al Odah v. United States, 321 F.3d 1134 (D.C. Cir. 2003).

Al-Bihani v. Obama, 590 F.3d 866 (D.C. Cir. 2010) („Al Bihani I”).

Al-Bihani v. Obama, 594 F.Supp.2d 35 (D.D.C. 2009).

Al-Bihani v. Obama, 619 F.3d 1 (D.C. Cir. 2010) („Al Bihani II”).

Al-Marri v. Pucciarelli, 534 F.3d 213 (4 $4^{\text {th }}$ Cir. 2008) (en banc).

Al-Marri v. Wright, 487 F.3d 160 (4 $4^{\text {th }}$ Cir. 2007).

The Ambrose Light, 25 F. 408 (S.D.N.Y. 1885).

American Baptist Churches in the U.S.A. v. Meese, 712 F.Supp. 756 (N.D. Cal. 1989).

The Amy Warwick (The Prize Cases), 67 U.S. (2 Black) 635 (1863).

Bank of Columbia v. Okely, 17 U.S. (4 Wheat.) 235 (1819).

Barron v. Baltimore, 32 U.S. (7 Pet.) 243 (1833).

Bas v. Tingy, 4 U.S. (4 Dall.) 37 (1800).

Boumediene v. Bush, 553 U.S. 723 (2008).

Bourn's Case, Cro. Jac. 543, 79 Eng. Rep. 465 (K.B. Mich. 17 Jac. I).

Bowsher v. Synar, 478 U.S. 714 (1986).

Braden v. 30th Judicial Circuit Court of Kentucky, 410 U.S. 484 (1973).

Bravo v. United States, 532 F.3d 1154 (11 ${ }^{\text {th }}$ Cir. 2008).

Breard v. Greene, 523 U.S. 371 (1998).

Bridges v. Wixon, 326 U.S. 135 (1945).

Brown v. Allen, 344 U.S. 443 (1953).

Brown v. United States, 12 U.S. (8 Cranch) 110 (1814).

Campbell v. Clinton, 203 F.3d 19 (D.C. Cir. 2000). 
Case of Fries, 9 F.Cas. 826 (C.C.D.Pa. 1799) (No. 5126).

Cherokee Nation v. Georgia, 30 U.S. (5 Pet.) 1, 8 L.Ed. 25 (1831).

Chevron U.S.A. Inc. v. Natural Resources Defense Council, Inc., 467 U.S. 837 (1984).

Christopher v. Harbury, 536 U.S. 403 (2002).

Colepaugh v. Looney, 235 F.2d 429 (10 ${ }^{\text {th }}$ Cir. 1956).

Cuban American Bar Ass'n, Inc. v. Christopher, 43 F.3d 1412 (11 $1^{\text {th }}$ Cir. 1995).

Dutton v. Warden, FCI Estill, 37 Fed.Appx. 51 ( $4^{\text {th }}$ Cir. 2002).

Erie R.R. Co.v. Tompkins, 304 U.S. 64 (1938).

Exparte Milligan, 71 U.S. (4 Wall.) 2 (1866).

Exparte Quirin, 317 U.S. 1 (1942).

Fleming v. Page, 50 U.S. (9 How.) 603, 13 L.Ed. 276 (1850).

Flores v. Southern Peru Copper Corp., 414 F.3d 233 ( $2^{\text {nd }}$ Cir. 2003).

Foster v. Neilson, 27 U.S. (2 Pet.) 253, 7 L.Ed. 415 (1829).

Garcia-Mirv. Meese, 788 F.2d 1446 (11 ${ }^{\text {th }}$ Cir. 1986).

Gersman v. Group Health Ass'n, Inc., 975 F.2d 886 (D.C. Cir. 1992).

Gherebi v. Bush, 374 F.3d 727 (9 $9^{\text {th }}$ Cir. 2004).

Haitian Centers Council, Inc. v. McNary, 969 F.2d 1326 (2 ${ }^{\text {nd }}$ Cir. 1992).

Haitian Refugee Ctr. v. Gracey, 809 F.2d 794 (D.C. Cir. 1987).

Hamdan v. Rumsfeld, 415 F.3d 33 (D.C. Cir. 2005).

Hamdan v. Rumsfeld, 548 U.S. 557 (2006).

Hamdi v. Rumsfeld, 316 F.3d 450, 185 A.L.R. Fed. 751 ( $4^{\text {th }}$ Cir. 2003).

Hamdi v. Rumsfeld, 542 U.S. 507 (2004).

Hamilton v. McClaughry, 136 F. 445 (C.C.D. Kan. 1905).

Handel v. Artukovic, 601 F.Supp. 1421 (C.D. Cal. 1985).

Harbury v. Deutch, 233 F.3d 596 (D.C. Cir. 2000).

Head Money Cases, 112 U.S. 580 (1884).

Hirabayashi v. United States, 320 U.S. 81 (1943).

Holmes v. Laird, 459 F.2d 1211 (D.C. Cir. 1972).

Hopfmann v. Connolly, 471 U.S. 459 (1985) (per curiam).

Hurtado v. California, 110 U.S. 516 (1884).

Huynh Thi Anh v. Levi, 586 F.2d 625 (6 ${ }^{\text {th }}$ Cir. 1978).

Igartua-De La Rosa v. United States, 417 F.3d 145 ( $1^{\text {st }}$ Cir. 2005) (en banc).

In re Goering and Others (Major War Criminals Case), 13 Ann. Dig. 203, 41 Am. J. Int'l L. 172

(I.M.T. (Nuremberg) 1946).

In re Medina, 19 I. \& N. Dec. 734, Interim Decision 3078 (B.I.A. 1988).

In re Territo, 156 F.2d 142 (9 $9^{\text {th }}$ Cir. 1946).

In re Wulzen, 235 F. 362 (S.D. Ohio 1916).

In re Yamashita, 327 U.S. 1 (1946).

Iwanowa v. Ford Motor Co., 67 F.Supp.2d 424 (D.N.J. 1999).

Jifry v. FAA, 370 F.3d 1174 (D.C. Cir. 2004).

Jobson's Case, Latch 160, 82 Eng. Rep. 325 (K.B. 14 Jac. I).

Jogi v. Voges, 425 F.3d 367 (7 $7^{\text {th }}$ Cir. 2005).

Johnson v. Eisentrager, 339 U.S. 763 (1950). 
Jones v. United States, 137 U.S. 202 (1890).

Kaoru Yamataya v. Fisher, 189 U.S. 86 (1903).

Khalid v. Bush, 355 F.Supp.2d 311 (D.D.C. 2005).

Khan v. Obama, 741 F.Supp.2d 1 (D.D.C. 2010).

King v. Overton, 1 Sid. 387, 82 Eng. Rep. 1173 (K.B. Mich. 20 Car. II).

King v. The Earl of Crewe ex parte Sekgome, 2 K.B. 576 (C.A.) (1910).

Kiyemba v. Obama, 555 F.3d 1022 (D.C. Cir. 2009) (Kiyemba I).

Kiyemba v. Obama, 561 F.3d 509 (D.C. Cir. 2009) (Kiyemba II).

Linder v. Calero Portocarrero, 747 F.Supp. 1452 (S.D. Fla. 1990).

Little v. Barreme, 6 U.S. (2 Cranch) 170 (1804).

Luckey v. Miller, 929 F.2d 618 (11 $1^{\text {th }}$ Cir. 1991).

Madison-Hughes v. Shalala, 80 F.3d 1121 (6 $6^{\text {th }}$ Cir. 1996).

Marks v. United States, 161 U.S. 297 (1896).

Mathews v. Diaz, 426 U.S. 67 (1976).

McCulloch v. Maryland, 17 U.S. (4 Wheat.) 316 (1819).

McLellan v. Mississippi Power \& Light Co., 545 F.2d 919 ( $5^{\text {th }}$ Cir. 1977) (en banc).

Medellin v. Texas, 552 U.S. 491 (2008).

Miller v. The Resolution, 2 U.S. (2 Dall.) 19 (Ct. App. in Cases of Capture 1781).

Mitchell v. Laird, 488 F.2d 611 (D.C. Cir. 1973).

Montoya v. United States, 180 U.S. 261 (1901).

Moyer v. Peabody, 212 U.S. 78 (1909).

National Council of Resistance of Iran v. Albright, 251 F.3d 192 (D.C. Cir. 2001).

The Nereide, 13 U.S. (9 Cranch) 388, 3 L.Ed. 769 (1815).

Padilla ex rel. Newman v. Bush, 233 F.Supp.2d 564 (S.D.N.Y. 2002).

Padilla v. Hanft, 389 F.Supp.2d 678 (D.S.C. 2005).

Padilla v. Hanft, 423 F.3d 386 ( $4^{\text {th }}$ Cir. 2005).

Padilla v. Rumsfeld, 352 F.3d 695 ( $2^{\text {nd }}$ Cir. 2003).

Pan Am. World Airways, Inc. v. Aetna Casualty \& Surety Co., 505 F.2d 989 ( $2^{\text {nd }}$ Cir. 1974).

The Paquete Habana, 175 U.S. 677 (1900).

People's Mojahedin Org. of Iran v. U.S. Dep't of State, 182 F.3d 17 (D.C. Cir. 1999).

Plyler v. Doe, 457 U.S. 202 (1982).

Rasul v. Bush, 542 U.S. 466 (2004).

Rasul v. Myers, 563 F.3d 527 (D.C. Cir. 2009).

Reid v. Covert, 354 U.S. 1 (1957).

Rodriguez de Quijas v. Shearson/American Express, Inc., 490 U.S. 477 (1989).

Ross v. McIntyre, 140 U.S. 453 (1891).

Russell v. Commissioner, 678 F.2d 782 ( $9^{\text {th }}$ Cir. 1982).

Russian Volunteer Fleet v. United States, 282 U.S. 481 (1931).

Shaughnessy v. Mezei, 345 U.S. 206 (1953).

Sosa v. Alvarez-Machain, 542 U.S. 692 (2004).

Spaulding v. Douglas Aircraft Co., 154 F.2d 419 (9 $9^{\text {th }}$ Cir. 1946).

Sutton v. Tiller, 46 Tenn. 593, 98 Am.Dec. 471, 1869 WL 2594 (1869).

Talbot v. Seeman, 5 U.S. (1 Cranch) 1 (1801). 
Tel-Oren v. Libyan Arab Republic, 726 F.2d 774 (D.C. Cir. 1984).

Texas Co. v. State ex rel. Coryell, 180 P.2d 631, 198 Okla. 565 (1945).

The Three Friends, 166 U.S. 1 (1897).

United States v. 129 Packages, 27 F.Cas. 284 (C.C.E.D.Mo. 1806) (No. 15,941).

United States v. Fort, 921 F.Supp. 523 (N.D. Ill. 1996).

United States v. Lindh, 212 F.Supp.2d 541 (E.D.Va. 2002).

United States v. Noriega, 808 F.Supp. 791 (S.D. Fla. 1992).

United States v. Rahman, 189 F.3d 88 (2 ${ }^{\text {nd }}$ Cir. 1999).

United States v. Smith, 27 F.Cas. 1192 (C.C.D.N.Y. 1806) (No. 16,342).

United States v. Verdugo-Urquidez, 494 U.S. 259 (1990).

Verano v. De Angelis Coal Co., 41 F.Supp. 954 (M.D. Pa. 1941).

Vermilya-Brown Co. v. Connell, 335 U.S. 377 (1948).

Warafi v. Obama, 409 Fed.Appx. 360 (D.C. Cir. 2011).

Whitney v. Robertson, 124 U.S. 190 (1888).

Wong Wing v. United States, 163 U.S. 228 (1896).

Woods v. Interstate Realty Co., 337 U.S. 535 (1949).

Yick Wo v. Hopkins, 118 U.S. 356 (1886).

Youngstown Sheet \& Tube Co. v. Sawyer, 343 U.S. 579 (1952).

Zadvydas v. Davis, 533 U.S. 678 (2001).

\section{Pisma procesowe}

Appendix to the Petition for Certiorari, Rasul v. Bush, Docket No. 03-343, 542 U.S. 466 (U.S. 2003), 2 IX 2003.

Brief for Louis Henkin et al. as Amici Curiae, Hamdan v. Rumsfeld, No. 05-184, 548 U.S. 557 (U.S. 2006).

Brief for Petitioner-Appellant, Al-Bihani v. Obama, No. 09-5051, 590 F.3d 866 (D.C. Cir. 2010). Brief for the Petitioner, Rumsfeld v. Padilla, No. 03-1027, 542 U.S. 426 (2004), 17 III 2004. Brief for the Respondents, Boumediene v. Bush, Nos. 06-1195, 06-1196, 553 U.S. 723 (2008), 9 X 2007.

Brief for the Respondents, Hamdi v. Rumsfeld, Docket No. 03-6696, 542 U.S. 507 (2004), 29 III 2004.

Brief for United States, Rasul v. Bush, Docket No. 03-334, 542 U.S. 466 (U.S. 2004), 3 III 2004. Brief of Amici Curiae International Law Professors Listed Herein in Support of Petitioner, Hamdan v. Rumsfeld, No. 05-184, 548 U.S. 557 (U.S. 2006), 5 I 2006.

Brief of Amici Curiae Senators John McCain, Lindsey Graham, and Kelly Ayotte in Support of Appellants, Hedges v. Obama, Nos. 12-3176, 12-3644, 2012 WL 3999839 (2 ${ }^{\text {nd }}$ Cir. 2012), 13 XI 2012.

Respondents' Memorandum Regarding the Government's Detention Authority Relative to Detainees Held at Guantanamo Bay (Docket \#1690), In re: Guantanamo Bay Detainee Litigation, Misc. No. 08-442 (TFH), 616 F.Supp.2d 63 (D.D.C. 2009), 13 III 2009.

Transcript of Oral Argument, Hamdi v. Rumsfeld, No. 03-6696, 542 U.S. 507 (2004), 28 IV 2004. 
Unclassified Brief for the Appellees, Al-Bihani v. Obama, No. 09-5051, 590 F.3d 866 (D.C. Cir. 2010).

\section{Projekty ustaw}

Enemy Belligerent Interrogation, Detention, and Prosecution Act, $111^{\text {th }}$ Cong., S. 3081 (2010).

Enemy Belligerent Interrogation, Detention, and Prosecution Act, $111^{\text {th }}$ Cong., H.R. 4892 (2010).

Enemy Combatant Detention Review Act of 2008, $110^{\text {th }}$ Cong., S. 3401 (2008).

Detainee Security Act of 2011, $112^{\text {th }}$ Cong., H.R. 968 (2011).

National Defense Authorization Act for FY 2011, 112 ${ }^{\text {th }}$ Cong., H.R. 1540 (2011).

National Defense Authorization Act for FY 2011, 112 ${ }^{\text {th }}$ Cong., S. 1867 (2011).

Military Detainee Procedures Improvement Act of 2011, 112 ${ }^{\text {th }}$ Cong., S. 551 (2011).

Terrorist Detention Review Reform Act, $111^{\text {th }}$ Cong., S. 3707 (2010).

\section{Inne źródła}

Akerman A. T., Unlawful Traffic with Indians, 13 Op. Att'y Gen. 470 (1871).

Bellinger III, J. B., Legal Issues in the War on Terrorism, Address at the London School of Economics, London, 31 X 2006.

Bush G. W., Letter to Congressional Leaders Reporting on Combat Action in Afghanistan against al Qaida Terrorists and Their Taliban Supporters, 9 X 2001, $107^{\text {th }}$ Cong., $1^{\text {st }}$ Sess., 2001 Week. Comp. Pres. Doc. 1447.

Butler B. F., Existence of War with the Seminoles, 3 Op. Att'y Gen. 307 (1838).

Bybee J. S., Determination of Enemy Belligerency and Military Detention, 26 Op. O.L.C., 2002 WL 34482990 (8 VI 2002) (preliminary print).

Bybee J.S., Re: Application of Treaties and Laws to al Qaeda and Taliban Detainees, Memorandum for A. R. Gonzales, Counsel to the President, and W. J. Haynes II, General Counsel of the Department of Defense (O.L.C. 22 I 2002) (unpublished opinion).

Bybee J. S., Re: The President's Power as Commander in Chief to Transfer Captured Terrorists to the Control and Custody of Foreign Nations, 26 Op. O.L.C., 2002 WL 34482991 (13 III 2002) (preliminary print).

Executive Office of the President, Statement of Administration Policy on H.R. 1540, 24 V 2011, [online] http://www.whitehouse.gov/sites/default/files/omb/legislative/sap/112/saphr15 40_20110524.pdf.

Hamilton A., The Federalist No. 23 (1788), [w:] The Federalist, red. G. W. Carey, J. McClellan, Indianapolis 2001.

Hamilton A., The Federalist No. 34 (1788), [w:] The Federalist, red. G. W. Carey, J. McClellan, Indianapolis 2001.

Harmon J. M., Presidential Power to Use the Armed Forces Abroad without Statutory Authorization, 4A Op. O.L.C. 185 (1980).

House Armed Services Committee Press Release, 8 III 2011, [online] http://armedservices.house. gov/index.cfm/files/serve?File_id=b8435f9f-9a0b-4608-a410-de8ca8dfa602.

House Committee on Armed Services, Report to Accompany H.R. 6054 (Military Commissions Act of 2006), together with the Additional and Dissenting Views, H.R. Rep. No. 109-664, Part 1,15 IX 2006, $109^{\text {th }}$ Cong., $1^{\text {st }}$ Sess. 
House Rules and Manual, $112^{\text {th }}$ Congress, red. J. V. Sullivan, H. Doc. No. 111-157, $112^{\text {th }}$ Cong., $1^{\text {st }}$ Sess. (2012).

Implications of the Supreme Court's Boumediene Decision for Detainees at Guantanamo Bay, Cuba, Hearing Before the House Committee on Armed Services, H.A.S.C. No. 110-166, $110^{\text {th }}$ Cong., $2^{\text {nd }}$ Sess. (30 VII 2008).

Koh H.H., Legal Adviser, U.S. Department of State, The Obama Administration and International Law, Annual Meeting of the American Society of International Law, Washington, 25 III 2010, [online] http://www.state.gov/s/l/releases/remarks/139119.htm.

Lee Ch., Treason, 1 Op. Att'y Gen. 84 (1798).

Lieber F., Instructions for the Government of Armies of the United States in the Field, U.S. War Dep't, General Order No. 100 (24 IV 1863), Washington 1898.

Lincoln A., Proclamation Calling Forth the Militia and Convening an Extra Session of Congress, 12 Stat. 1258 (15 IV 1861).

National Commission on Terrorist Attacks Upon the United States, Final Report, Washington 2004, [online] http://www.gpo.gov/fdsys/pkg/GPO-911REPORT/pdf/GPO-911REPORT.pdf.

Philbin P. F., Legality of the Use of Military Commissions to Try Terrorists, 25 Op. O.L.C., 2001 WL 36175681 (6 XI 2001) (preliminary print).

Senate Committee on Foreign Relations, Report on the International Covenant on Civil and Political Rights, S. Exec. Rep. 102-23, $102^{\text {nd }}$ Cong., $1^{\text {st }}$ Sess., 31 I.L.M. 645 (1993).

Speed J., Reply of the Attorney General to the Resolution of the Senate Relative to the Prosecution of Jefferson Davis for Treason, 11 Op. Att'y Gen. 411 (1866).

U.S. Department of State, United States Responses to Selected Recommendations of the Human Rights Committee (2007).

Williams G. H., The Modoc Indian Prisoners, 14 Op. Att'y Gen. 249 (1873).

Yoo J. C., Applicability of 18 U.S.C. S 4001 (a) to Military Detention of United States Citizens, 26 Op. O.L.C., 2002 WL 34482988 (27 VI 2002) (preliminary print).

Yoo J. C., The President's Constitutional Authority to Conduct Military Operations against Terrorists and Nations Supporting Them, 25 Op. O.L.C., 2001 WL 34726560 (25 IX 2001) (preliminary print).

Yoo J. C., Delahunty R. J., Authority for Use of Military Force to Combat Terrorist Activities within the United States, 25 Op. O.L.C., 2001 WL 36190674 (23 X 2001) (preliminary print).

\section{PRZEDMIOTOWA}

Abramowitz D., The President, the Congress, and Use of Force: Legal and Political Considerations in Authorizing Use of Force against International Terrorism, „Harvard International Law Journal" 2002, Vol. 43.

Baker Jr. J. S., A War, Yes; against Terror, No, „Michigan State Journal of International Law” 2010, Vol. 19.

Baty T., Morgan J. H., War. Its Conduct and Legal Results, London 1915.

Bellia Jr. A. J., Clark B. R., The Federal Common Law of Nations, „Columbia Law Review” 2009, Vol. 109. 
Bellinger III J. B., A Counterterrorism Law in Need of Updating, „Washington Post” 2010, 26 XI, [online] http://www.washingtonpost.com/wp-dyn/content/article/2010/11/25/.html.

Bellinger III J. B., Padmanabhan V. M., Detention Operations in Contemporary Conflicts: Four Challenges for the Geneva Conventions and Other Existing Law, "American Journal of International Law" 2011, Vol. 105, [online] http://dx.doi.org/10.5305/ amerjintelaw.105.2.0201.

Blackstone W., Commentaries on the Laws of England (1765-1769), red. G. Sharswood, B. Field, Philadelphia 1893.

Bradley C. A., Chevron Deference and Foreign Affairs, „Virginia Law Review” 2000, Vol. 86, [online] http://dx.doi.org/10.2307/1073844.

Bradley C. A., Goldsmith J. L., Congressional Authorization and the War on Terrorism, „Harvard Law Review" 2005, Vol. 118.

Bradley C. A., Goldsmith J. L., Customary International Law as Federal Common Law: A Critique of the Modern Position, „Harvard Law Review” 1997, Vol. 110, [online] http:// dx.doi.org/10.2307/1342230.

Bradley C. A., Goldsmith J. L., Foreign Relations Law. Cases and Materials, New York 2009.

Bynkershoek C. van, Quaestionum juris publici libri duo (1737), Oxford 1930, Classics of International Law, 14. Publications of the Carnegie Endowment for International Peace, Division of International Law.

Carnahan B. M., In re Medina: Are the 1949 Geneva Conventions Self-Executing?, „Air Force Law Review" 1987, Vol. 26.

Cerone J., Misplaced Reliance on the "Law of War”, „New England Journal of International and Comparative Law" 2007, Vol. 14.

Chesney R. M., Who May be Held? Military Detention through the Habeas Lens, „Boston College Law Review” 2011, Vol. 52.

Chesney R. M., Goldsmith J. L., Terrorism and the Convergence of Criminal and Military Detention Models, „Stanford Law Review” 2008, Vol. 60.

Coke E., Institutes of the Laws of England, in Four Parts (1628-1644), London 1794-1797.

Davis K. C., An Approach to Problems of Evidence in the Administrative Process, „Harvard Law Review"1942, Vol. 55, [online] http://dx.doi.org/10.2307/1335092.

Einspanier K. L., Burlamaqui, the Constitution, and the Imperfect War on Terror, „Georgetown Law Journal" 2008, Vol. 96.

Elsea J. K., Grimmett R. F., Declarations of War and Authorizations for the Use of Military Force. Historical Background and Legal Implications, CRS Report for Congress RL31133, Washington 2011.

Falkoff M. D., Knowles R., Bagram, Boumediene, and Limited Government, „DePaul Law Review" 2010, Vol. 59.

Fallon R. H. [i in.], Hart and Wechsler's The Federal Courts and the Federal System, New York 2003, University Casebook Series.

Federal Procedure. Lawyers Edition, St. Paul 1981-2013 (wersja elektroniczna dostępna w systemie Westlaw).

Fischer M. P., Applicability of the Geneva Conventions to "Armed Conflict” in the War on Terror, „Fordham International Law Journal” 2007, Vol. 30. 
Fisher L., Presidential War Power, Lawrence 2004.

Garcia M. J. [i in.], Closing the Guantanamo Detention Center. Legal Issues, CRS Report for Congress R40139, Washington 2011.

Garraway Ch., Afghanistan and the Nature of Conflict, [w:] The War in Afghanistan. A Legal Analysis, red. M. N. Schmitt, Newport 2009, International Law Studies, 85.

Garrett B. L., Habeas Corpus and Due Process, „Cornell Law Review” 2012, Vol. 98.

Geltzer J. A., Decisions Detained: The Court's Embrace of Complexity in Guantanamo-Related Litigation, „Berkeley Journal of International Law” 2010, Vol. 29.

Geltzer J. A., Of Suspension, Due Process, and Guantanamo: The Reach of the Fifth Amendment after Boumediene and the Relationship between Habeas Corpus and Due Process, „University of Pennsylvania Journal of Constitutional Law” 2012, Vol. 14.

Goldsmith J. L., The Terror Presidency. Law and Judgment inside the Bush Administration, New York 2007.

Goodman R., Jinks D., International Law, U.S. War Powers, and the Global War on Terrorism, „Harvard Law Review” 2005, Vol. 118.

Gorman S. D., In the Wake of Tragedy: The Citizens Cry Out for War, but Can the United States Legally Declare War on Terrorism?, „Penn State International Law Review” 2003, Vol. 21.

Grimmett R. F., Authorization for Use of Military Force in Response to the 9/11 Attacks (P.L. 107-40). Legislative History, CRS Report for Congress RS22357, Washington 2006.

Grotius H., The Rights of War and Peace (De iure belli ac pacis, libri tres; 1620), red. R.Tuck, Indianapolis 2005.

Hafetz J., Calling the Government to Account: Habeas Corpus in the Aftermath of Boumediene, „Wayne Law Review” 2011, Vol. 57.

Hale M., Historia placitorum coronae. The History of the Pleas of the Crown (1736), red. S. Emlyn, E. Ingersoll, W. A. Stokes, Philadelphia 1847.

Hawkins W., A Treatise of the Pleas of the Crown (1716), red. J. Curwood, London 1824, Making of Modern Law.

Henkin L., Foreign Affairs and the United States Constitution, Oxford-New York 1996.

Henkin L., International Law as Law in the United States, „Michigan Law Review” 1984, Vol. 82, [online] http://dx.doi.org/10.2307/1288495.

Hertz R., Liebman J. S., Federal Habeas Corpus Practice and Procedure, New Providence 2011.

Hollander B. N., The President and Congress - Operational Control of the Armed Forces. „Military Law Review" 1965, Vol. 27.

Hyde Ch. Ch., International Law, Chiefly as Interpreted and Applied by the United States, Boston 1922.

Preux J. de, Siordet F., Geneva Convention Relative to the Treatment of Prisoners of War. Commentary, przel. A. P. de Heney, Geneva 1960, The Geneva Conventions of 12 August 1949, red. J. S. Pictet, t. 3.

Jinks D., September 11 and the Laws of War, „Yale Journal of International Law” 2003, Vol. 28. Jinks D., Sloss D., Is the President Bound by the Geneva Conventions?, "Cornell Law Review” 2004, Vol. 90.

Katz S. N., A New American Dilemma? U.S. Constitutionalism vs. International Human Rights, „University of Miami Law Review” 2003, Vol. 58. 
Keitner Ch. I., Rights beyond Borders, „Yale Journal of International Law” 2011, Vol. 36.

Killian J. H., Costello G. A., Thomas K. R. [i in.], The Constitution of the United States of America. Analysis and Interpretation. Analysis of Cases Decided by the Supreme Court of the United States to June 28, 2002, Washington 2004, Senate Documents, 108-17.

Klein A., Wittes B., Preventive Detention in American Theory and Practice, „Harvard National Security Journal" 2011, Vol. 2.

Koch Ch. H., Administrative Law and Practice, Eagan 2010.

Koh H. H., Is International Law Really State Law?, „Harvard Law Review” 1998, Vol. 111.

Kuhn W. E., The Terrorist Detention Review Reform Act: Detention Policy and Political Reality, „Seton Hall Legislative Journal” 2011, Vol. 35.

Lewis G. G., Mewha J., History of Prisoner of War Utilization by the United States Army, 1776-1945, Washington 1955, Dep't of the Army Pamphlet, 20-213.

Lobel J., The Use of Force to Respond to Terrorist Attacks: The Bombing of Sudan and Afghanistan, „Yale Journal of International Law” 1999, Vol. 24.

Marcinko M., „Status terrorysty” w świetle międzynarodowego prawa humanitarnego, [w:] Walka z terroryzmem w świetle prawa międzynarodowego, red. K. Lankosz, M. Chorośnicki, P. Czubik, Bielsko-Biała 2005.

McGinnis J. O., Losing the Law War: The Bush Administration's Strategic Errors, „Georgia State University Law Review" 2008, Vol. 25.

Mortlock D., Definite Detention: The Scope of the President's Authority to Detain Enemy Combatants, „Harvard Law \& Policy Review” 2010, Vol. 4.

Murphy R., Radsan A. J., Due Process and Targeted Killing of Terrorists, „Cardozo Law Review” 2009, Vol. 31.

Murphy S. D., Decision Not to Regard Persons Detained in Afghanistan as POWs, "American Journal of International Law" 2002, Vol. 96, [online] http://dx.doi.org/10.2307/2693945.

Nanda V. P., Pansius D. K., Litigation of International Disputes in U.S. Courts, Eagan 2005 (wersja elektroniczna dostępna w systemie Westlaw) (suplement 2013).

Nesbitt N. H., Meeting Boumediene's Challenge: The Emergence of an Effective Habeas Jurisprudence and Obsolescence of New Detention Legislation, "Minnesota Law Review” 2010, Vol. 95.

Neuman G. L., The Extraterritorial Constitution after Boumediene v. Bush, „Southern California Law Review" 2009, Vol. 82.

Operational Law Handbook, red. S. Condron, Charlottesville 2011.

Oppenheim L. F. L., International Law, t. 2: War and Neutrality, London 1906.

Parks W. H., Combatants, [w:] The War in Afghanistan. A Legal Analysis, red. M. N. Schmitt, Newport 2009, International Law Studies, 85.

Paulsen M. S., Youngstown Goes to War, „Constitutional Commentary” 2002, Vol. 19.

Paust J. J., War and Enemy Status after 9/11: Attacks on the Laws of War, „Yale Journal of International Law" 2003, Vol. 28.

Posner E. A., Sunstein C. R., Chevronizing Foreign Relations Law, „Yale Law Journal” 2007, Vol. 116.

Priester B. J., Terrorist Detention: Directions for Reform, „University of Richmond Law Review” 2009, Vol. 43. 
Ramsey M. D., The Constitution's Text in Foreign Affairs, Cambridge (Mass.) 2007.

Restatement of the Law, Third: Foreign Relations Law of the United States, Philadelphia 1987.

Rosas A., The Legal Status of Prisoners of War. A Study in International Humanitarian Law Applicable in Armed Conflicts, Helsinki 1976, Annales Academiae Scientiarum Fennicae. Dissertationes Humanarum Litterarum, 9.

Rotunda R. D., Nowak J. E., Treatise on Constitutional Law. Substance and Procedure, St. Paul 2007.

Shumate B. E., New Rules for a New War: The Applicability of the Geneva Conventions to al Qaeda and Taliban Detainees Captured in Afghanistan, "New York International Law Review" 2005, Vol. 18.

Solum, L. B., Stare Decisis, Law of the Case, and Judicial Estoppel, [w:] Moore's Federal Practice, red. D. R. Coquillette [i in.], t. 18, New York 2007.

Sparrow T. L., Indefinite Detention after Boumediene: Judicial Trailblazing in Uncharted and Unfamiliar Territory, „Suffolk University Law Review” 2011, Vol. 44.

Sprout H. H., Theories as to the Applicability of International Law in the Federal Courts of the United States, „American Journal of International Law” 1931, Vol. 26, [online] http:// dx.doi.org/10.2307/2189349.

Stern R. L., Gressman E., Supreme Court Practice, Washington 2002.

Stromseth J. E., Understanding Constitutional War Powers Today: Why Methodology Matters, „Yale Law Journal” 1996, Vol. 106, [online] http://dx.doi.org/10.2307/797312.

Turns D., The Treatment of Detainees and the „Global War on Terror”: Selected Legal Issues, [w:] International Law and Military Operations, red. M. D. Carsten, Newport 2008, International Law Studies, 84.

Vattel E. de, The Law of Nations, or, the Principles of Law of Nature (1758), red. B. Kapossy, R. Whatmore, Indianapolis 2008, Natural Law and Enlightenment Classics.

Vazquez C. M., The Four Doctrines of Self-Executing Treaties, „American Journal of International Law" 1995, Vol. 89, [online] http://dx.doi.org/10.2307/2203933.

Vladeck S. I., The D.C. Circuit after Boumediene, „Seton Hall Law Review” 2011, Vol. 41.

Vladeck S. I., Insular Thinking about Habeas, „Iowa Law Review Bulletin” 2012, Vol. 97.

Vladeck S. I., Lederman, M. S., The NDAA: The Good, the Bad, and the Laws of War - Part II, Lawfare, 31 XII 2011, [online] http://www.lawfareblog.com/2011/12/the-ndaa-the-good-the-bad-and-the-laws-of-war-part-ii/.

Wallach E. J., Partisans, Pirates, and Pancho Villa: How International and National Law Handled Non-State Fighters in the "Good Old Days” before 1949 and that Approach's Applicability to the „War on Terror”, „Emory International Law Review” 2010, Vol. 24.

Wedgwood R., Responding to Terrorism: The Strikes against bin Laden, „Yale Journal of International Law" 1999, Vol. 24.

Weingarten J., The Detention of Enemy Combatants Act, „Harvard Journal on Legislation” 2006, Vol. 43.

Weisburd A. M., The Executive Branch and International Law, „Vanderbilt Law Review” 1988, Vol. 41.

Winthrop W., Military Law and Precedents, Washington 1920, Document (United States. War Department), 1001. 
Wittes B., Chesney R. M., Reynolds L., The Emerging Law of Detention 2.0. The Guantánamo Habeas Cases as Lawmaking, Governance Studies at Brookings, Washington 2012, [online] http://www.brookings.edu/ /media/research/files/reports//5/guantanamo\%20wittes/05_guantanamo_wittes.pdf.

Wittes B., House-Senate Side-by-Side of NDAA Provisions: Part I, Lawfare, 7 XII 2011, [online] http://www.lawfareblog.com/2011/12/house-senate-side-by-side-of-ndaa-provisions-part-i/.

Wittes B., Klaidman Post \#1: Where that March 13 Brief Came From, Lawfare, 10 VI 2012, [online] http://www.lawfareblog.com/2012/06/klaidman-post-1-where-that-march-13-brief-came-from/.

Wormuth F. D., Firmage E. B., To Chain the Dog of War. The War Power of Congress in History and Law, Urbana 1989.

Wright Ch. A., Miller A. R., Federal Practice and Procedure, St. Paul 1969-2012.

Young E. A., Sorting Out the Debate over Customary International Law, „Virginia Journal of International Law” 2002, Vol. 42.

Zeisberg M. A., War Powers. The Politics of Constitutional Authority, Princeton 2013.

Mgr Dariusz STOLICKI - doktorant w Katedrze Konstytucjonalizmu i Ustrojów Państwowych Instytutu Nauk Politycznych i Stosunków Międzynarodowych UJ, absolwent politologii UJ. Jego zainteresowania badawcze obejmują m.in. system ustrojowy i prawny Stanów Zjednoczonych, prawo konstytucyjne porównawcze (szczególnie krajów anglosaskich), historię common law oraz badania nad legislacją i parlamentaryzmem. 